
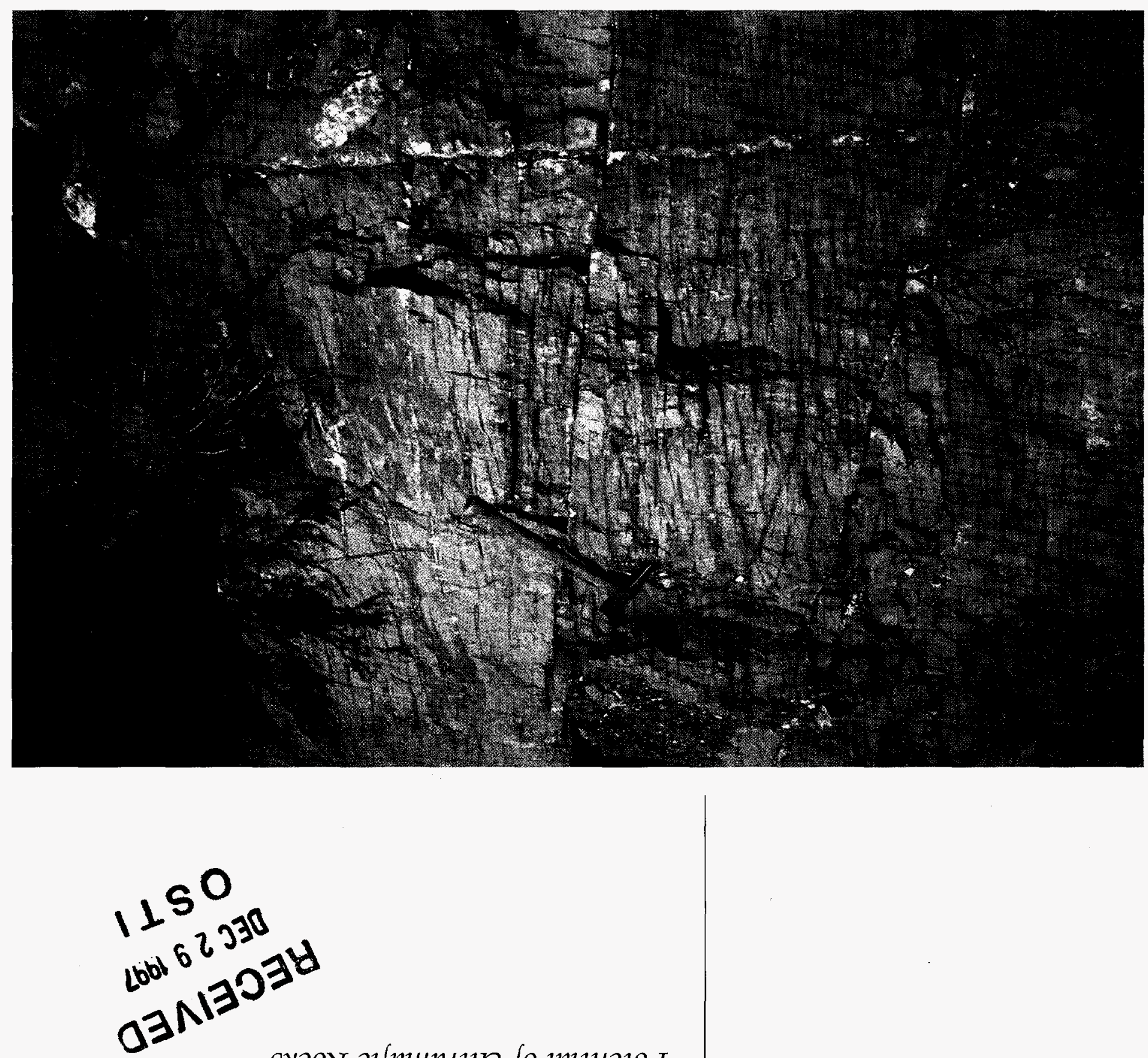

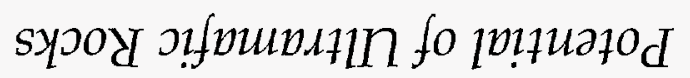
8ut.razsanbas aptxo!̣ uoqub

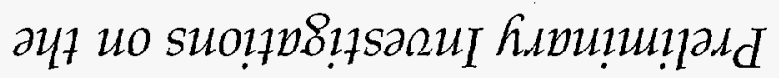


Prepared by Lanny Piotrowski, Group EES-1

Cover Photo: Photo of serpentinized harzburgite from the Del Puerto ultramafic body, California: Massive, relatively unaltered rocks are cut by network of serpentine veins (hammer handle is $46 \mathrm{~cm}$ long).

An Affirmative Action/Equal Opportunity Employer

This report was prepared as an account of work sponsored by an agency of the United States Government. Neither The Regents of the University of California, the United States Government nor any agency thereof, nor any of their employees, makes any warranty, express or implied, or assumes any legal liability or responsibility for the accuracy, completeness, or usefulness of any information, apparatus, product, or process disclosed, or represents that its use would not infringe privately owned rights. Reference herein to any specific commercial product, process; or service by trade name, trademark, manufacturer, or otherwise, does not necessarily constitute or imply its endorsement, recommendation, or favoring by The Regents of the University of California, the United States Government, or any agency thereof. The views and opinions of authors expressed herein do not necessarily state or reflect those of The Regents of the University of California, the United States Government, or any agency thereof. Los Alamos National Laboratory strongly supports academic freedom and a researcher's right to publish; as an institution, however, the Laboratory does not endorse the viewopoint of a publication or guarantee its technical correctness. 
Preliminary Investigations on the

Carbon Dioxide Sequestering

Potential of Ultramafic Rocks

Fraser Goff

George Guthrie

Dale Counce

Emily Kluk

Deborah Bergfeld

Marjorie Snow

DIGTRBUTION OF THIS DOCUMENT IS UNHMTIED

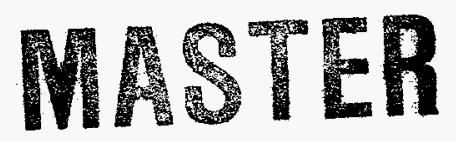




\section{DISCLAmier}

Portions of this docoment myy be illegible in electronic image produets. Images are produced from the best arailable origionl docomentert 


\title{
Preliminary Investigations on the Carbon Dioxide Sequestering Potential of Ultramafic Rocks
}

Fraser Goff, George Guthrie, Dale Counce, Emily Kluk,

Deborah Bergfeld, and Marjorie Snow

\begin{abstract}
Fossil fuels continue to provide major sources of energy to the modern world even though global emissions of $\mathrm{CO}_{2}$ are presently at levels of $19 \mathrm{Gt} / \mathrm{yr}$. Future antipollution measures may include sequestering of waste $\mathrm{CO}_{2}$ as magnesite $\left(\mathrm{MgCO}_{3}\right)$ by processing ultramafic rocks to obtain reactable $\mathrm{Mg}$. Huge ultramafic deposits consisting of relatively pure $\mathrm{Mg}$-rich silicates exist throughout much of the world in ophiolites and layered intrusions. Peridotites (especially dunites) and serpentinites comprise the best ores because they contain the most $\mathrm{Mg}$ by weight and are relatively reactive to hot acids such as $\mathrm{HCl}$. Although mining such deposits on a large scale would have environmental impacts, the sequestering process could provide $\mathrm{Cr}, \mathrm{Ni}$, and other metals as byproducts and could dispose of existing waste ("white") asbestos. Small ultramafic bodies $\left(\sim 1 \mathrm{~km}^{3}\right)$ can potentially sequester about $1 \mathrm{Gt}$ of $\mathrm{CO}_{2}$ or about $20 \%$ of annual US emissions. A single large deposit of dunite $\left(\sim 30 \mathrm{~km}^{3}\right)$ could dispose of about $20 \mathrm{yr}$ of current US $\mathrm{CO}_{2}$ emissions. The cost and environmental impact of mining these deposits must be weighed against the increased costs of energy and benefits to the atmosphere and climate.
\end{abstract}

\subsection{INTRODUCTION}

Numerous resource evaluations show that worldwide reserves of fossil fuels can provide mankind's energy needs for many centuries (e.g., United Nations, 1995), but the major drawback of consuming these resources is that $\mathrm{CO}_{2}$ emissions into the atmosphere will steadily increase. The United States already produces about $5 \mathrm{Gt}$ of $\mathrm{CO}_{2}$ annually, over $25 \%$ of the present global output of 19 Gt. These quantities are an order of magnitude greater than the average yearly production of $\mathrm{CO}_{2}$ by volcanoes and metamorphic processes and an order of magnitude greater than the consumption rate of $\mathrm{CO}_{2}$ by natural geologic processes (Kerrick et al., 1995). During the last two centuries, $\mathrm{CO}_{2}$ levels in the atmosphere have increased approximately $30 \%$ (Ramanathan, 1988) raising legitimate concerns about global climate change (Weart, 1997; Broecker, 1997).

Various schemes have been proposed that would reduce $\mathrm{CO}_{2}$ emissions while allowing continued consumption of fossil fuels (Blok et al., 1992). Lackner et al. (1995) described two chemical processes to sequester $\mathrm{CO}_{2}$ as carbonate minerals.
These processes would combine $\mathrm{CO}_{2}$ with divalent cations (principally $\mathrm{Mg}$ and/or $\mathrm{Ca}$ ) derived from natural mineral deposits by either direct carbonation at high temperature or by reactions in aqueous solution. At this stage of research, both processes look thermodynamically favorable but details of actual implementation require further investigation.

Magnesium and calcium make up about 2.0 and $2.1 \mathrm{~mol} \%$ of the Earth's crust, respectively, primarily bound in silicate minerals (Brownlow, 1979). Although molar abundances are similar, $\mathrm{Mg}$ silicates contain more reactive material per ton of rock as a result of the lower molecular weight of $\mathrm{Mg}$. Also, pure deposits of $\mathrm{Mg}$ silicates are more widely distributed and abundant than $\mathrm{Ca}$ silicate deposits. Finally, two types of Mg silicate minerals occur in relatively pure deposits that have thermodynamic and chemical properties desirable for carbon dioxide waste processing. These minerals, forsterite and serpentine, are relatively soluble in hot $\mathrm{HCl}$. The rocks in which these minerals occur are peridotites and serpentinites, two types of $u l$ tramafic rocks (rocks rich in $\mathrm{Mg}$ and $\mathrm{Fe}$ ). 
The object of this paper is to discuss the geologic distribution, geochemistry, and acid dissolution properties of peridotites and serpentinites. We have also provided very preliminary resource assessments of two "ore bodies" (one from each type of deposit) and have calculated the $\mathrm{CO}_{2}$ sequestering potential of eight ultramafic deposits in the United States.

\subsection{RESOURCES}

\subsection{Distribution, Origin, and Age}

As mentioned above, the magnesium-rich, ultramafic rocks (primarily peridotites and serpentinites) that we envision as best candidates for ores in the sequestering process, are distributed throughout the world. There are at least nine types of ultramafic rock associations, but they occur in magmatic-tectonic settings too varied to document here (Coleman, 1977). The most voluminous and widespread ultramafic rocks are the alpine peridotites that form the basal sequence of unique rock associations called ophiolites. Ophiolites are slabs of oceanic crust uplifted and eroded along subduction zones and plate boundaries. The basal peridotites represent detached slices of the Earth's upper mantle exposed by these tectonic processes. Because they occur mostly along the upper plate of present and past subduction zones, ophiolites are found as belts throughout most of the world (Fig. 1), having discontinuously exposed dimensions of as much as $1000 \mathrm{x}$ $100 \mathrm{~km}$. The younger belts are found primarily along continental margins, but older belts are exposed in older tectonic terraines. Famous ophiolite massifs occur in the Alps (type locality), the Oman, and New Caledonia. The one continent having relatively little ophiolite is Africa.

Within North America (Fig. 2), ophiolites are found along the Appalachian mountain chain stretching from the southeast US into Quebec and Newfoundland and along the Cordilleran chain stretching from Alaska to California. The Appalachian belt resulted from uplift and deformation during earlyto mid-Paleozic subduction along the east coast of North America, but the Cordilleran belt resulted from several late-Paleozoic to early-Tertiary subduction events along the west coast. Smaller but perhaps equally famous ophiolite belts also occur in the Caribbean (particularly Cuba) and in Guatemala (Chuacus Mountains). These latter belts are found along present, transform-fault, plate boundaries (the North American and Caribbean plates separated by the Motagua fault zone in Guatemala).

When examined more closely, the basal ultramafic rocks in ophiolite belts are found to be elongate ribbons and fragments that parallel regional geologic structures (Fig. 3). The tectonic processes that create ophiolites and expose elongate fragments of the upper mantle are complex and usually take several million years to complete (Fig. 4). Individual exposures of ultramafic rock may occupy hundreds of square kilometers or may be as small as hand samples incorporated into fault zones.

The second most voluminous class of ultramafic rocks occurs in large, layered intrusions at localized spots worldwide. These magma bodies generally had initial compositions similar to mantle basalt and were intruded into shallow levels of the Earth's crust (usually $\leq 8 \mathrm{~km}$ ). The larger bodies tend to be Precambrian age $(\geq 650 \mathrm{Ma})$. Because of their great initial volumes, these magmas cooled slowly within the crust and the first formed minerals of crystallization (primarily Mg-rich silicates) settled by gravity toward the bottom of the intrusions. As a result, layers of peridotite as thick as a few hundred meters can be found in exposures as long as several tens of kilometers at some sites. The largest such body is the famous Bushveld Complex in South Africa, but other well-known bodies occur at the Stillwater, Sudbury, and Skaergaard locations in North America (Fig. 2). Of these three, the late Archean $(2.7 \mathrm{Ga})$ Stillwater Complex in Montana has the largest exposures of gravity-settled peridotite in North America (about $48 \mathrm{~km}$ long; Czamanske and Zientek, 1985).

Ultramafic rocks contain many mineral resources. They are the primary source of chrome, platinum group metals, nickel, and cobalt; however, they 


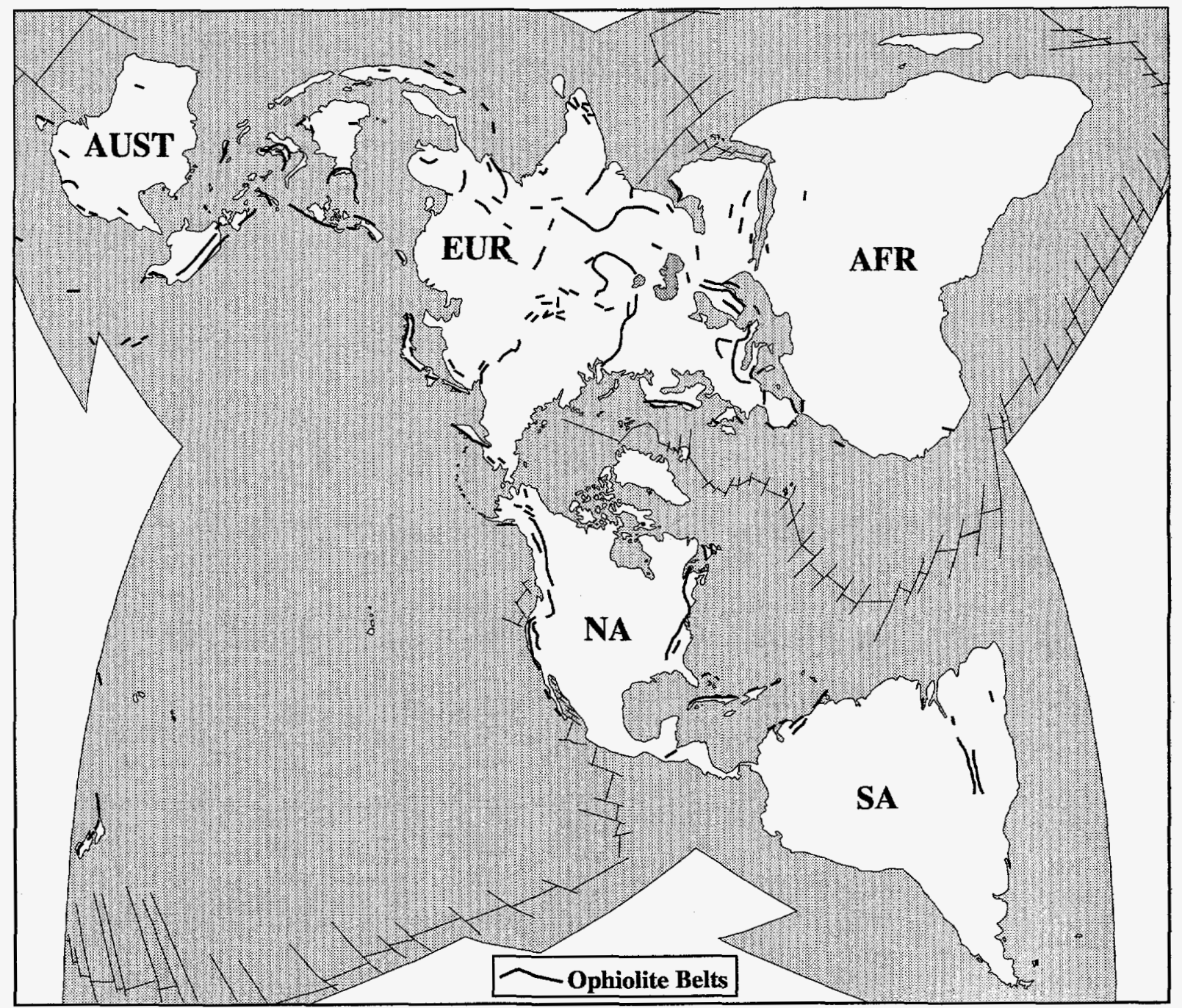

Fig. 1. Polar projection of the world showing generalized locations of ophiolite belts (from Coleman, 1977).

may also be a source of manganese, copper, mercury, and other metals. Diamonds are found in ultramafic pipes (magmatic conduits) called kimberlites. Chrysotile asbestos is mined from serpentinites (O’Hanley, 1996).

\subsection{Geochemistry and Mineralogy of Perido- tites and Serpentinites}

Most alpine peridotites (Coleman, 1977) consist primarily of $\mathbf{M g}$-rich olivine (forsterite, $\left.(\mathrm{Mg}, \mathrm{Fe})_{2} \mathrm{SiO}_{4}\right)$ with lesser amounts of $\mathrm{Mg}$-rich orthopyroxene (enstatite, $\left.(\mathrm{Mg}, \mathrm{Fe}) \mathrm{SiO}_{3}\right)$, clinopyroxene, and chromite (chrome spinel, $\mathrm{FeCr}_{2} \mathrm{O}_{4}$ ). The clinopyroxene, usually $\mathrm{Cr}$-rich diopside, contains some $\mathrm{Ca}, \mathrm{Al}, \mathrm{Ti}$, and $\mathrm{Na}$. Typical alpine peridotites contain $\geq 10 \%$ orthopyroxene and are called harzburgites (Fig. 5). If the composi- tion contains $\geq 10 \%$ clinopyroxene, the peridotite is called lherzolite. Peridotites with $\geq 90 \%$ olivine are called dunites. The olivine in alpine peridotites generally contains $88 \%$ to $94 \%$ of the $\mathrm{Mg}$ component, and coexisting pyroxenes contain up to $7 \mathrm{wt} \% \mathrm{Al}$ (Fig. 6). Peridotites with low concentrations of $\mathrm{Al}$ and alkali metals are more desirable as ores (discussed below).

Peridotite horizons in layered intrusions typically are richer in the two pyroxene minerals than alpine peridotites (Hess, 1960). Under the microscope, olivine and orthopyroxene in alpine peridotites usually display shears, semiparallel fractures, deformed crystal structures, and kink bands resulting from the stresses that the rocks have undergone during subduction and emplacement. These features are usually absent within the same 


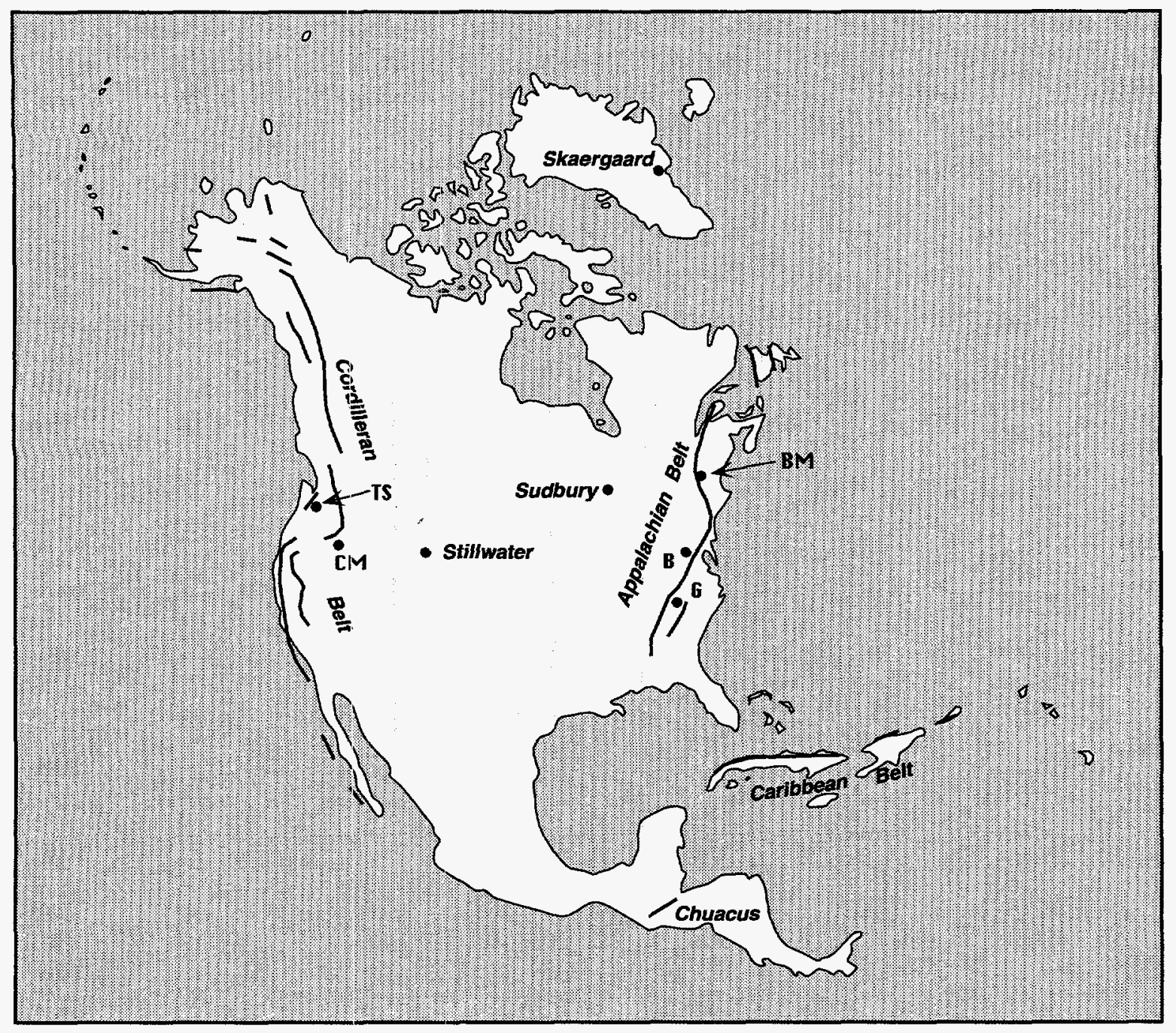

Fig. 2. Locations of ophiolite belts and major layered intrusions of North America. Example ophiolite bodies mentioned in text are: $\mathrm{B}=\mathrm{Baltimore}$ Complex; $\mathrm{BM}=$ Belvidere Mountain; $\mathrm{CM}=$ Canyon Mountain; $\mathrm{G}=\mathrm{Green}$ Mountain; TS = Twin Sisters (Coleman, 1977, and references in text).

minerals of layered intrusions. Chemical analyses of some peridotite bodies in the US, which highlight alpine peridotites and the Stillwater intrusion, are listed in Table 1.

Usually peridotites within ophiolite sequences and layered intrusions are partly to completely reconstituted into hydrated Mg-rich silicates (serpentine and related minerals). The hydration products form by reaction of peridotites with seawater and groundwaters during various stages of their evolution and tectonic history (Coleman, 1971, 1977; O'Hanley, 1996). The various metamorphic processes that operate during serpentinization are much too complex to review here. The resulting serpentinites may contain some relict olivine and pyroxene, but more often they contain only serpentine minerals $\left.\left(\mathrm{Mg}_{3}\left(\mathrm{Si}_{2} \mathrm{O}_{5}\right)(\mathrm{OH})_{4}\right)\right)$, magnetite (Fe-rich spinel), and residual chromite, plus brucite $\left(\mathrm{Mg}(\mathrm{OH})_{2}\right.$ ), carbonates (usually magnesite, $\left.\mathrm{MgCO}_{3}\right)$, and silica $\left(\mathrm{SiO}_{2}\right)$. The latter three minerals are most common along veins and fractures but can be pervasive. Serpentinites may contain as much as $14 \mathrm{wt} \%$ water. Chromite, the least reactive of the original minerals, is usually preserved. Microscopic examination of serpentinite textures reveals that the serpentine minerals retain crystal shapes and other characteristics of original peridotite minerals (O’Hanley, 1996).

The three serpentine minerals (lizardite, chrysotile, antigorite) are isochemical with very similar 


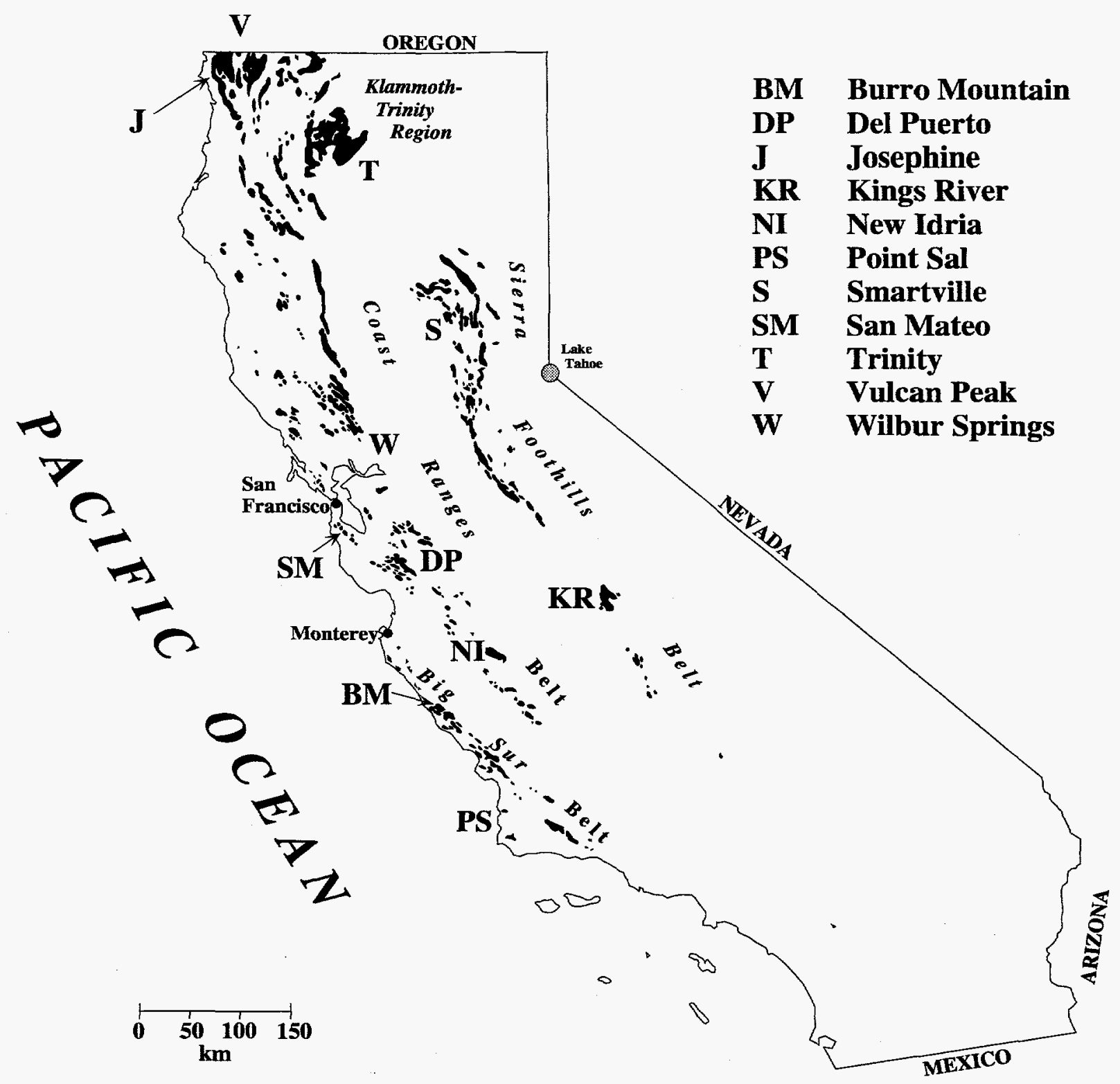

Fig. 3. Map of California (modified from Jennings, 1977) showing locations of ultramafic provinces and some example sites described in text; the Vulcan Peak peridotite in extreme southern Oregon is actually part of the greater Josephine ophiolite, the largest in North America.

sheet-like structures. When subjected to stress, chrysotile sheets roll into the elongate fibers known as asbestos. Lizardite and chrysotile are the most common serpentine minerals and form at lower temperatures than antigorite $\left(<250^{\circ} \mathrm{C}\right)$. Textural evidence in rocks shows that the hydration of forsterite to form serpentine (and brucite) is accompanied by a volume increase (as much as 53\%). Thus, the serpentinites are low-density rocks (about $2.6 \mathrm{~g} / \mathrm{cm}^{3}$ ) relative to the original peridotites (about $\left.3.3 \mathrm{~g} / \mathrm{cm}^{3}\right)$. Serpentine breaks down above $500^{\circ} \mathrm{C}$ to forsterite + talc + water (O'Hanley, 1996).
Chemical analyses of serpentinites are given in Table 2. Because of their lower densities and high water contents, serpentinites contain substantially less $\mathrm{Mg}$ than peridotites (compare with Table 1). On the other hand, unaltered peridotites in large volumes $\left(>1 \mathrm{~km}^{3}\right)$ are much less common in nature because of their high reactivity in the geologic environment. Table 1 highlights some of the larger, unaltered peridotites in the US.

Because ultramafic rocks are low in $\mathrm{K}$ and $\mathrm{P}$, they sustain a unique flora and fauna that are noticeable to even the most casual of observers 


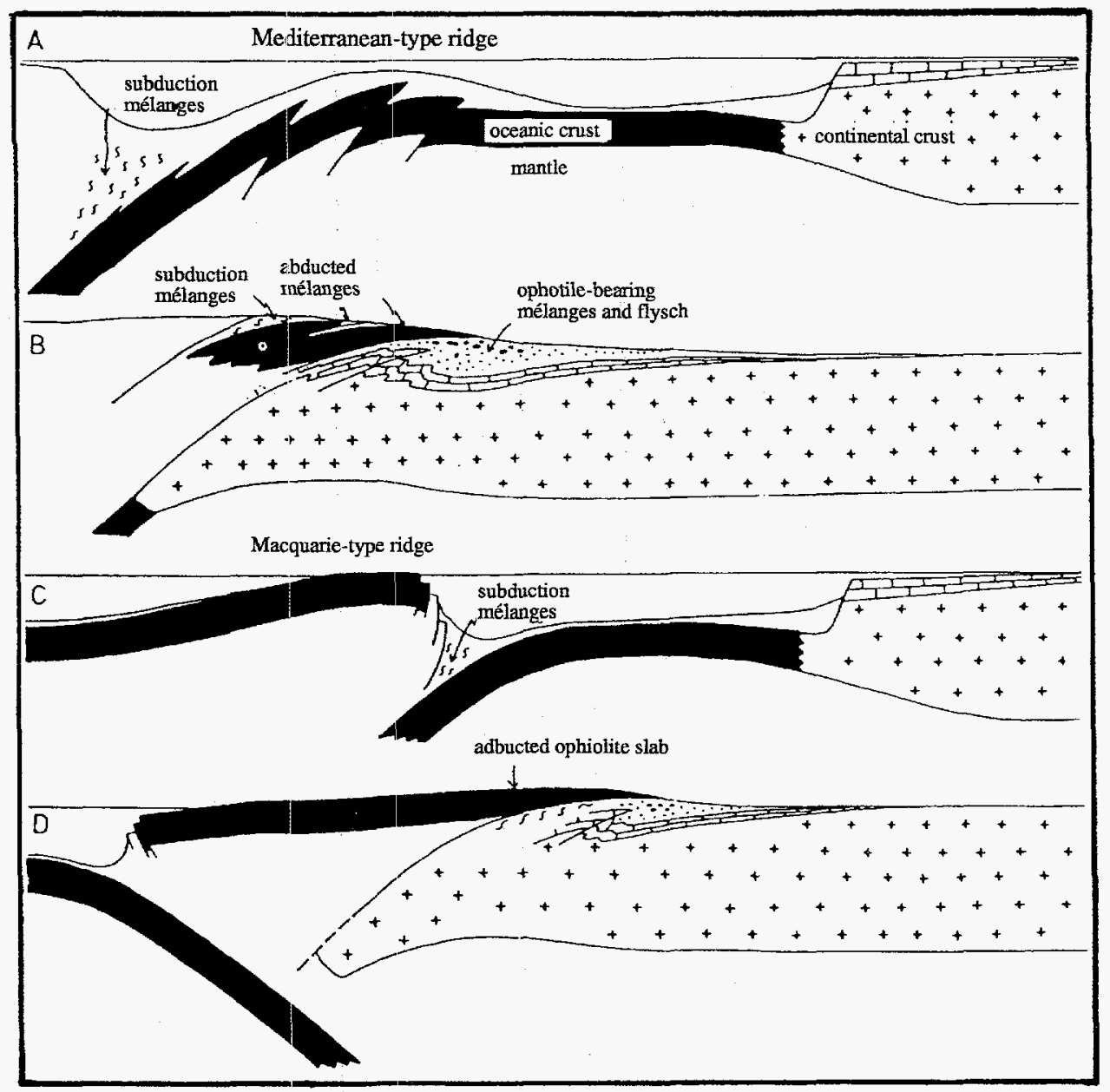

Fig. 4. Schematic diagrams showing various mechanisms for emplacement of ophiolites; Fig. 4-D shows the mechanism most similar to the western margin of North America (from Coleman, 1977). The detailed mechanisms of ophiolite emplacement are much more complicated than these cross-sectional drawings.

(O'Hanley, 1996). Most grasses will not grow on serpentinites; instead, one observes a restricted assemblage of thorny brush and pines. Ultramafic soils tend to be brick red to dark orange from oxidation of Fe. Near-surface outcrops combine these bright soil colors with the greens, grays, and blacks of the host rock. Sharp vegetation and soil contrasts occur along contacts between ultramafic rocks and other formations.

\subsection{Best Ultramafic Ores for Carbonate Dis- posal}

As described below, olivine and serpentine minerals are relatively soluble in hot $\mathrm{HCl}$ at relatively low pressure. In fact, mineralogists of an earlier era used hot, 1:1 HCl as a test for olivine and serpentine (Berry and Mason, 1959). The reaction produces a yellow-green acidic solution containing divalent cations (primarily $\mathrm{Mg}^{+2}$ and $\mathrm{Fe}^{+2}$ ) and residual silica gel ( \pm water). In contrast, spinels and pyroxenes do not dissolve readily in the $\mathrm{HCl}$. These residual minerals and the silica must be separated from the acid solution before the sequestering process can continue. Although $\mathrm{Cr}$-spinel (and other potentially valuable metals) may contribute greatly to the economics of the whole process, the pyroxenes contribute virtually nothing of value. Thus, peridotites and serpentinites with little pyroxene comprise the most desirable ores.

Fresh dunite (or any unserpentinized peridotite for that matter) is relatively uncommon in large quantities. The largest such body in the US is the Twin Sisters Dunite (Ragan, 1963) in the Cascade Range of northwest Washington (Fig. 2; Table 1). This 


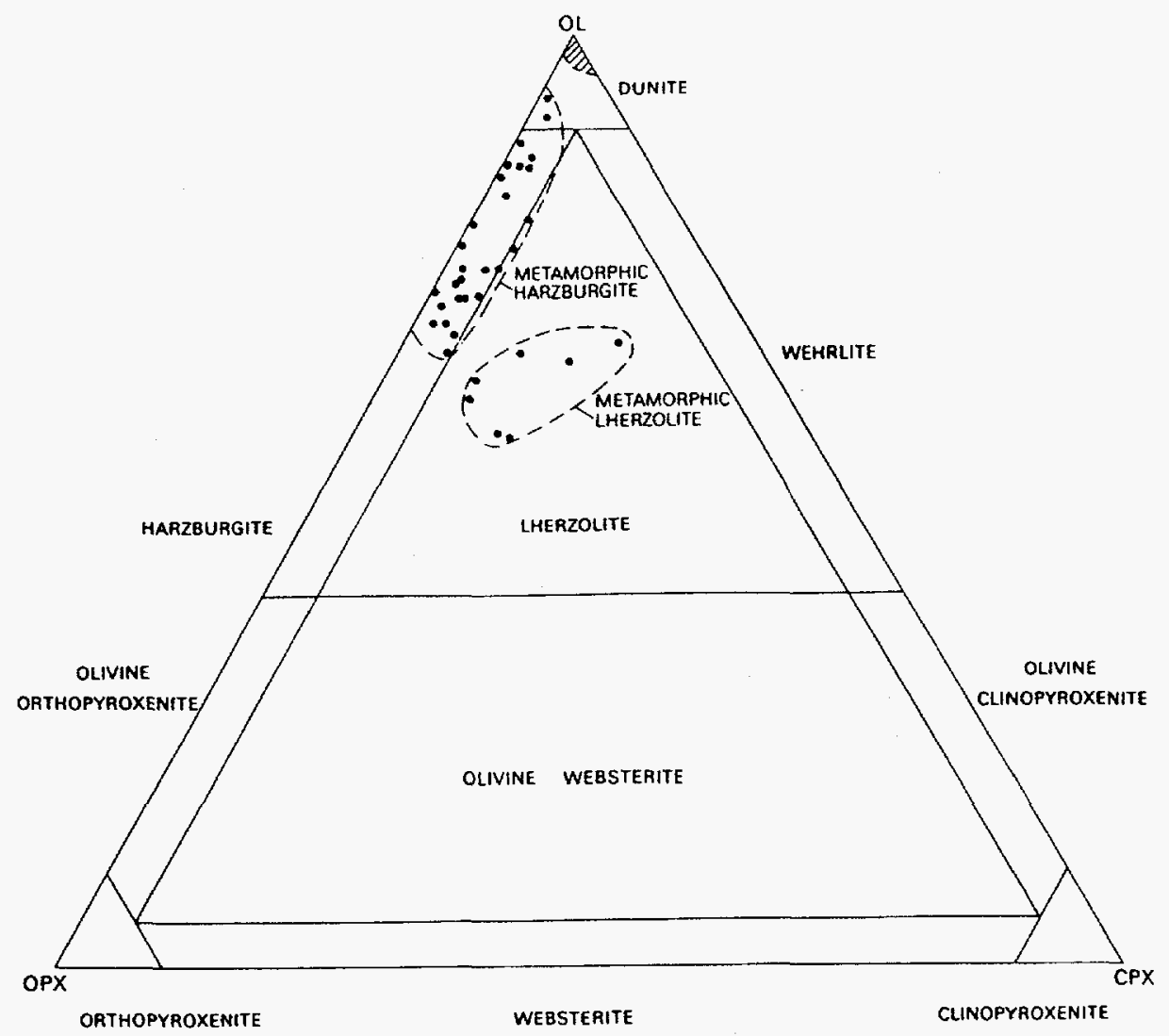

Fig. 5. Modal proportions of olivine, orthopyroxene, and clinopyroxene in harzburgite and dunite from alpine peridotites (Coleman, 1977).

dunite mass covers roughly $90 \mathrm{~km}^{2}$ and is presently mined by open-pit methods for refractory (foundry) sand. Our examination of a large (20$\mathrm{kg}$ ) sample provided by the operator shows that it contains $\leq 4 \%$ serpentine and other secondary reaction products. A relatively large, unserpentinized peridotite named the Green Mountain Peridotite $\left(\geq 5 \mathrm{~km}^{2}\right)$ occurs in the Appalachians of North Carolina and is also mined primarily for foundry sand. This material contains $\geq 5 \%$ orthopyroxene and roughly $10 \%$ of high-grade metamorphic products including talc and amphibole (minerals not soluble in $\mathrm{HCl}$; see Appendix A). This material is less desirable than dunite as an ore even though it contains nearly comparable amounts of $\mathrm{Mg}$.

Partially serpentinized peridotite and dunite in large masses (20\% to $80 \%$ serpentine) are more common. Examples include the Belvidere Mountain prospect in Vermont (Labotka and Albee, 1979), the Canyon Mountain and Vulcan Peak deposits in Oregon (Thayer, 1977; Himmelberg and Loney, 1973), the Del Puerto and Burro Mountain bodies of California (Himmelberg and Coleman, 1968; Page, 1967), and others (Figs. 2 and 3; Table 1). The Belvidere, Vulcan Peak, and Del Puerto masses contain small zones $\left(<1 \mathrm{~km}^{2}\right)$ of relatively unaltered dunite.

Completely serpentinized peridotite is exceptionally common in certain areas of the eastern and western US. The Baltimore Complex contains $\geq 80 \%$ serpentinite (Fig. 2), and nearly all the California deposits shown in Fig. 3 consist of $\geq 95 \%$ sepentinite (Morgan, 1977; Rice, 1957; Table 2). The Wilbur Springs body in north-central California covers over $200 \mathrm{~km}^{2}$ (Rice, 1957). Perhaps the largest body of continuous serpentine outcrop in the US occurs in the Josephine Peridotite of northwest California, extending over at least 800 $\mathrm{km}^{2}$ (Harper, 1984). These deposits, although huge, display variable alteration of mostly harzburgite and are not so desirable as the unaltered dunites. Some occur in rather remote locations that make them economically unattractive. 
(a)

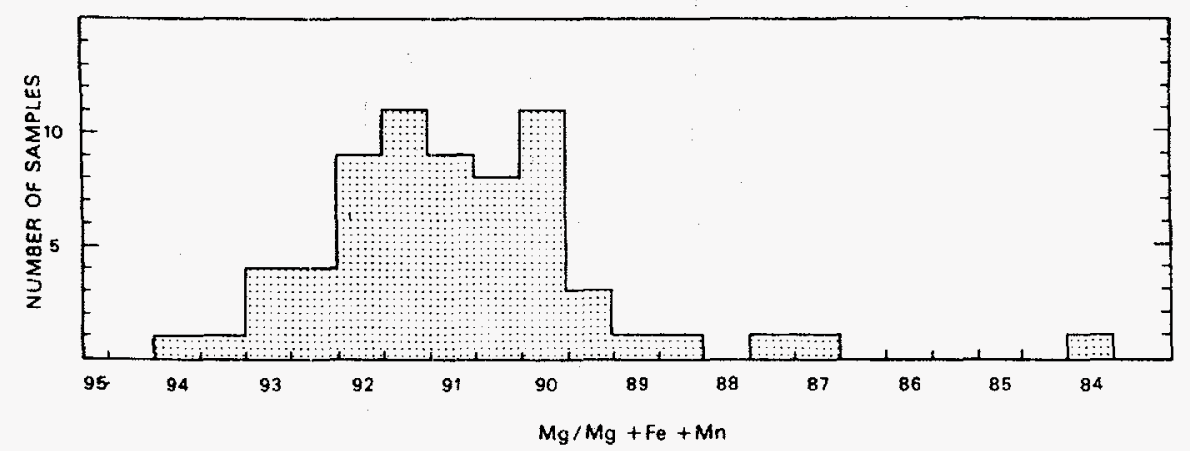

(b)
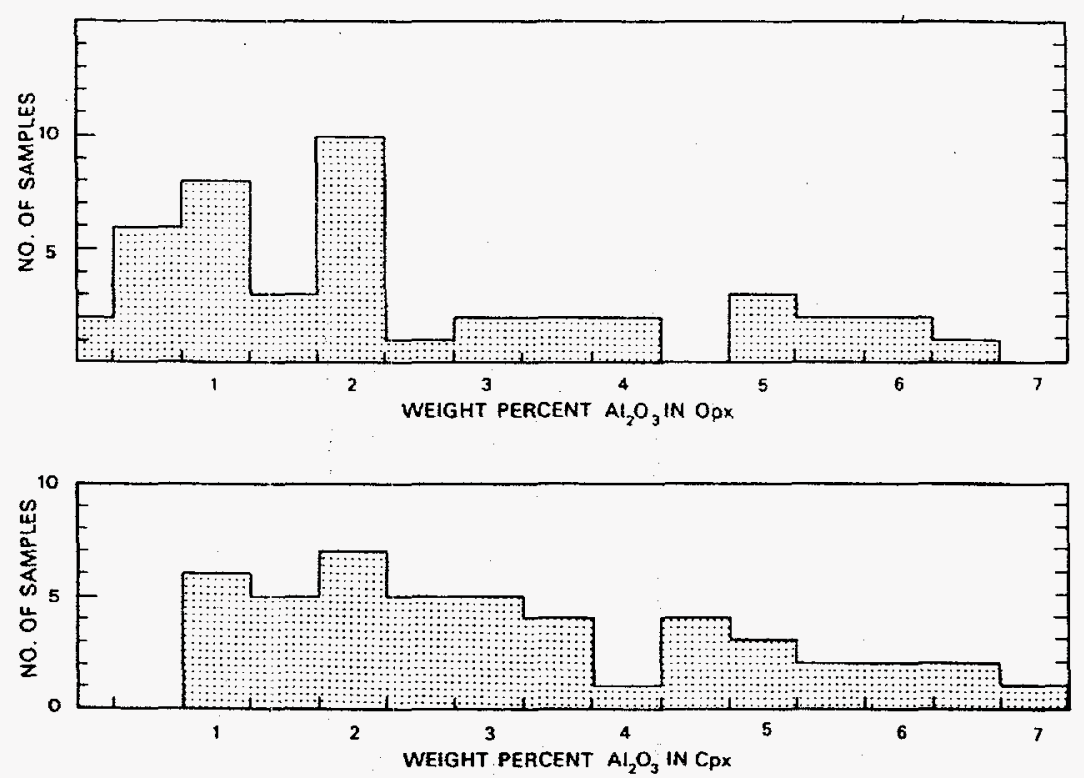

Fig. 6. Histograms showing (a) the range in composition of olivines from alpine peridotites; (b) the range in $\mathrm{Al}_{2} \mathrm{O}_{3}$ contents of orthopyroxene (opx) and clinopyroxene (cpx) from alpine peridotites (Coleman, 1977).

\subsection{ACID DISSOLUTION EXPERIMENTS}

We conducted a variety of experiments on several ultramafic rock samples to compare analyses resulting from $\mathrm{HCl}$ dissolution to those resulting from dissolution by a more common rock reagent $(\mathrm{HCl}-$ $\mathrm{HNO}_{3}-\mathrm{HF}$ ). X-ray fluorescence (XRF) analyses and standard values for some samples are listed in Table 3. The results of these experiments show that

1. Hot $\mathrm{HCl}$ is better at dissolving $\mathrm{Mg}$ from ultramafic rocks than the three-reagent mixture ( $\geq 35 \mathrm{wt} \%$ versus $\leq 15 \mathrm{wt} \% \mathrm{Mg}$ ). $\mathrm{Re}$ sidual products (about 45 to $60 \mathrm{wt} \%$ ) from $\mathrm{HCl}$ dissolution include silica gel, spinels, and pyroxenes and additional silicates such as talc, amphiboles, chlorite, and sericite.
The three-acid mixture apparently precipitates $\mathrm{MgF}$ compounds while dissolving the rock.

2. Hot $\mathrm{HCl}$ is slightly better at dissolving $\mathbf{M g}$ from serpentinite than from peridotite, including dunite, because serpentinites contain less nonreactive silicates such as pyroxene. Much of the Fe in serpentinites occurs as microcrystalline magnetite that is relatively easy to dissolve in $\mathrm{HCl}$.

3. Hot $\mathrm{HCl}$ is less effective at dissolving many trace metals from ultramafic rocks than the three-acid mixture. This is especially true for high field-strength elements like $\mathrm{Cr}$ and slightly true for $\mathrm{Mn}$. On the other hand, Co (not listed in Table 3) and Ni mainly reside in olivine; thus, $\mathrm{HCl}$ dissolution works well for these elements. 
Table 1: Chemical compositions of selected "fresh" ultramafic rocks (D and HZ mean dunite and harzburgite used in average).

\begin{tabular}{|c|c|c|c|c|c|c|c|c|c|c|c|}
\hline \multirow[b]{2}{*}{$\begin{array}{c}\text { Sample } \\
\text { Type }\end{array}$} & \multicolumn{3}{|c|}{$\begin{array}{l}\text { Del Puerto } \\
\text { CA }\end{array}$} & \multirow{2}{*}{$\begin{array}{c}\text { Cazadero } \\
\text { CA } \\
\begin{array}{c}\text { PCC-1 STD } \\
\text { Hzbgite }\end{array}\end{array}$} & \multirow{2}{*}{$\begin{array}{c}\text { Stillwater } \\
\text { MT } \\
\text { ST-AVE } \\
\text { HZ+D }\end{array}$} & \multirow{2}{*}{$\begin{array}{c}\text { Canyon Mtn. } \\
\text { OR } \\
\text { CM-AVE }^{\mathrm{c}} \\
\text { Hzbgite }\end{array}$} & \multicolumn{3}{|c|}{$\begin{array}{c}\text { Vulcan Peak } \\
\text { OR. }\end{array}$} & \multirow{2}{*}{$\begin{array}{c}\text { Twin Sisters } \\
\text { WA }\end{array}$} & \multirow{2}{*}{$\begin{array}{c}\text { Belvidere Mtn. } \\
\text { VT } \\
\text { BM-AV } \\
\text { Dunite }\end{array}$} \\
\hline & $\begin{array}{l}\text { UM96-19a } \\
\text { Dunite }\end{array}$ & $\begin{array}{l}66 \mathrm{R} 22 \\
\text { Dunite }\end{array}$ & $\begin{array}{c}\text { 66R20 } \\
\text { Hzbgite }\end{array}$ & & & & $\begin{array}{c}\text { VP-AVE } \\
\text { D+HZ }\end{array}$ & $\begin{array}{c}\text { 19VP68 } \\
\text { Dunite }\end{array}$ & $\begin{array}{c}\text { 1VP68 } \\
\text { Hzbgite }\end{array}$ & & \\
\hline \multicolumn{12}{|c|}{ Major Elements (wt\%) } \\
\hline $\mathrm{SiO}_{2}$ & 38.75 & 39.0 & 44.9 & 41.71 & 47.7 & 42.1 & 41.2 & 39.6 & 43.4 & 40.41 & 39.7 \\
\hline $\mathrm{TiO}_{2}$ & 0.002 & 0.02 & 0.02 & 0.01 & 0.12 & 0.04 & 0.035 & 0.03 & 0.02 & 0.005 & 0.0 \\
\hline $\mathrm{Al}_{2} \mathrm{O}_{3}$ & 0.73 & 0.04 & 0.91 & 0.675 & 4.82 & 1.70 & 0.38 & 0.07 & 0.25 & 0.19 & 0.4 \\
\hline $\mathrm{Fe}_{2} \mathrm{O}_{3}$ & 4.72 & 2.8 & 0.80 & 2.72 & 2.94 & 2.49 & 1.52 & 1.1 & 0.52 & 1.03 & --- \\
\hline $\mathrm{FeO}$ & 4.68 & 5.0 & 7.0 & 5.06 & 6.54 & 4.79 & 6.93 & 9.8 & 7.8 & 6.97 & 8.9 \\
\hline $\mathrm{MnO}$ & 0.160 & 0.11 & 0.12 & 0.12 & 0.17 & 0.13 & 0.12 & 0.14 & 0.14 & 0.12 & 0.23 \\
\hline $\mathrm{MgO}$ & 46.43 & 46.1 & 43.0 & 43.43 & 29.0 & 35.6 & 45.5 & 47.4 & 45.3 & 49.59 & 48.3 \\
\hline $\mathrm{CaO}$ & 0.00 & 0.00 & 1.50 & 0.52 & 2.44 & 5.58 & 0.70 & 0.30 & 0.91 & 0.17 & $\ldots$ \\
\hline $\mathrm{Na}_{2} \mathrm{O}$ & 0.00 & 0.00 & 0.02 & 0.03 & 0.19 & 0.55 & 0.006 & 0.02 & 0.00 & 0.015 & ---- \\
\hline $\mathrm{K}_{2} \mathrm{O}$ & 0.00 & 0.23 & 0.08 & 0.007 & 0.02 & 0.03 & 0.068 & 0.06 & 0.07 & 0.001 & --- \\
\hline $\mathrm{P}_{2} \mathrm{O}_{5}$ & $<0.005$ & 0.03 & 0.03 & 0.002 & 0.01 & 0.02 & 0.032 & 0.04 & 0.04 & 0.002 & --- \\
\hline $\mathrm{NiO}$ & 0.386 & 0.35 & 0.32 & 0.31 & ---- & $\cdots$ & 0.26 & 0.27 & 0.25 & 0.30 & ---- \\
\hline $\mathrm{Cr}_{2} \mathrm{O}_{3}$ & 1.20 & 0.44 & 0.47 & 0.40 & 0.48 & ---- & 0.25 & 0.30 & 0.18 & 0.58 & 1.6 \\
\hline $\mathrm{CO}_{2}$ & ---- & 0.21 & $<0.05$ & 0.15 & 0.11 & 0.12 & $<0.06$ & 0.05 & $<0.05$ & 0.08 & $\ldots$ \\
\hline $\mathrm{H}_{2} \mathrm{O}(+)$ & 5.02 & 5.6 & 1.0 & 4.71 & 4.91 & 6.94 & 2.97 & 1.1 & 1.3 & 0.44 & 1.23 \\
\hline $\mathrm{H}_{2} \mathrm{O}(-)$ & ---- & 0.50 & 0.09 & 0.44 & 0.49 & ---- & 0.18 & 0.10 & 0.05 & 0.06 & --- \\
\hline TOTAL & 102.1 & 100.4 & 100.3 & 100.3 & 99.95 & 100.1 & 100.2 & 100.4 & 100.2 & 99.96 & 100.4 \\
\hline $\mathrm{MgO} / \mathrm{SiO}_{2}$ & 1.20 & 1.18 & 0.96 & 1.04 & 0.608 & 0.845 & 1.10 & 1.20 & 1.04 & 1.23 & 1.22 \\
\hline $\mathrm{Mol} \% \mathrm{MgO}$ & 52.5 & 51.1 & 52.7 & 49.6 & 35.5 & 40.4 & 53.2 & 57.0 & 54.6 & 59.9 & 57.9 \\
\hline$\rho\left(\mathrm{g} / \mathrm{cm}^{3}\right)$ & 3.25 & 2.83 & 3.22 & $(3.08)$ & $(3.07)$ & $(2.95)$ & (3.18) & $(3.28)$ & $(3.27)$ & (3.32) & $(3.27)$ \\
\hline$\%$ Serp & 10.0 & 58.5 & 10.0 & (34) & (35) & (50) & (21) & (9) & (10) & (4) & (10) \\
\hline
\end{tabular}

a single XRF analysis by EES-1; other Del Puerto analyses from Himmelberg and Coleman (1968).

b rock standard (Govindaraju, 1994).

c average of 26 (Hess, 1960).

$\mathrm{d}$ average of 11 (Thayer, 1977).

e average of 13; all Vulcan Peak analyses from Himmelberg and Looney (1973).

f rock standard (Govindaraju, 1994).

$\mathrm{g}$ average of 3 (Labotka and Albee, 1979). 
• Table 2: Chemical compositions of selected serpentinites and associated rocks.

\begin{tabular}{|c|c|c|c|c|c|c|}
\hline \multirow[b]{2}{*}{$\begin{array}{l}\text { Sample } \\
\text { Type } \\
\end{array}$} & \multicolumn{2}{|c|}{$\begin{array}{cl}\text { Del } & \begin{array}{l}\text { Puerto } \\
\text { CA }\end{array} \\
\end{array}$} & \multirow{2}{*}{$\begin{array}{c}\text { San Mateo } \\
\text { CA } \\
\text { FG96-312 } \\
\text { Sheared Serp. }\end{array}$} & \multirow{2}{*}{$\begin{array}{c}\text { Wilbur Springs } \\
\text { CA } \\
\text { WSS-AVE }^{\mathrm{d}} \\
\text { Massive Serp. }\end{array}$} & \multirow{2}{*}{$\begin{array}{c}\text { Baltimore Cplx. } \\
\text { MD } \\
\text { BCS-AVE } \\
\text { Serpentinite }\end{array}$} & \multirow{2}{*}{$\begin{array}{c}\text { Belvidere Mtn. } \\
\text { VT } \\
\text { BMS-AVE }^{\mathrm{f}} \\
\text { Serpentinite }\end{array}$} \\
\hline & $\begin{array}{l}\text { DPS-AVE } \\
\text { Serp. Perid. }\end{array}$ & $\begin{array}{c}\text { UM96-26 } \\
\text { Massive Serp. }\end{array}$ & & & & \\
\hline \multicolumn{7}{|c|}{ Major Elements (wt\%) } \\
\hline $\mathrm{SiO}_{2}$ & 38.8 & 40.8 & 41.08 & $40.6 \pm 1.2$ & 41.2 & 33.0 \\
\hline $\mathrm{TiO}_{2}$ & 0.013 & 0.011 & 0.054 & $0.040 \pm 0.02$ & 0.05 & 0.0 \\
\hline $\mathrm{Al}_{2} \mathrm{O}_{3}$ & 0.47 & 0.032 & 1.76 & $1.99 \pm 0.40$ & 1.33 & 0.6 \\
\hline $\mathrm{Fe}_{2} \mathrm{O}_{3}$ & 3.23 & 5.49 & 8.92 & $5.06 \pm 1.3$ & 6.17 & $\cdots$ \\
\hline $\mathrm{FeO}$ & 4.74 & 1.88 & ---- & $2.94 \pm 1$ & 2.43 & 14.1 \\
\hline $\mathrm{MnO}$ & 0.13 & 0.14 & 0.133 & $0.138 \pm 0.15$ & 0.12 & 0.2 \\
\hline $\mathrm{MgO}$ & 42.5 & 34.7 & 33.06 & $36.2 \pm 1.1$ & 35.09 & 38.0 \\
\hline $\mathrm{CaO}$ & 0.53 & 5.76 & 1.76 & $0.42 \pm 0.1$ & 1.67 & $-\cdots-$ \\
\hline $\mathrm{Na}_{2} \mathrm{O}$ & 0.013 & 0.00 & 0.00 & 0.00 & 0.01 & $-\cdots$ \\
\hline $\mathrm{K}_{2} \mathrm{O}$ & 0.15 & 0.00 & 0.00 & 0.00 & 0.06 & $-\cdots$ \\
\hline $\mathrm{P}_{2} \mathrm{O}_{5}$ & 0.051 & $<0.005$ & 0.011 & $<0.005$ & 0.008 & ---- \\
\hline $\mathrm{NiO}$ & 0.27 & 0.116 & 0.33 & $0.324 \pm 0.01$ & 0.18 & ---- \\
\hline $\mathrm{Cr}_{2} \mathrm{O}_{3}$ & 0.60 & 0.413 & 0.37 & $0.423 \pm 0.015$ & 0.16 & 0.7 \\
\hline $\mathrm{CO}_{2}$ & 0.18 & -.-- & ---- & $\cdots$ & 0.03 & ---- \\
\hline $\mathrm{H}_{2} \mathrm{O}(+)$ & 8.43 & 11.3 & 12.46 & $12.6 \pm 1.1$ & 11.06 & 12.5 \\
\hline $\mathrm{H}_{2} \mathrm{O}(-)$ & 0.45 & -..- & ---- & ---- & 0.31 & ---- \\
\hline TOTAL & 100.6 & 100.9 & 99.99 & 100.7 & 99.88 & 99.1 \\
\hline $\mathrm{MgO} / \mathrm{SiO}_{2}$ & 1.09 & 0.850 & 0.804 & 0.892 & 0.852 & 1.15 \\
\hline $\mathrm{Mol} \% \mathrm{MgO}$ & 45.6 & 36.7 & 35.5 & 37.6 & 37.7 & 39.3 \\
\hline$\rho\left(\mathrm{g} / \mathrm{cm}^{3}\right)$ & 2.85 & 2.69 & $(2.63)$ & $(2.65)$ & $(2.71)$ & $(2.63)$ \\
\hline$\%$ Serp & 56.1 & 90 & 100 & 95 & $(80)$ & 100 \\
\hline
\end{tabular}

a average of 8 (Himmelberg and Coleman, 1968).

$\mathrm{b}$ single analysis by EES-1.

$c$ average of 8 homogonized pieces $(2 \mathrm{~kg}$ ) analyzed by EES-1 (FeO not analyzed).

$\mathrm{d}$ average of 15 samples analyzed by EES-1.

e average of four (Morgan, 1977).

$f$ average of three; all $\mathrm{Fe}$ as $\mathrm{FeO}$ (Labotka and Albee, 1979). 
Table 3: Results of dissolution and analysis using $1 \mathrm{~g}$ of ultramafic rock sample mixed in hot, $1: 1 \mathrm{HCl}$ or in $\mathrm{HCl}-\mathrm{HNO}_{3}-\mathrm{HF}$. The results are compared with XRF analyses (D. Counce and E. Kluk, EES-1). The residues are primarily mixtures of silica gel, spinels, and pyroxenes. No single reagent can effectively dissolve all components from ultramafic rocks, but $\mathrm{HCl}$ is more effective at dissolving $\mathrm{Mg}$ than the mixed reagent and works better on serpentinites than peridotites.

\begin{tabular}{|c|c|c|c|c|c|}
\hline Sample Types & $\begin{array}{c}\text { Residue } \\
\text { (wt\%) }\end{array}$ & $\begin{array}{l}\mathrm{MgO} \\
\text { (wt\%) }\end{array}$ & Mn & $\begin{array}{c}\mathrm{Ni} \\
\text { (all ppm) } \\
\end{array}$ & $\mathrm{Cr}$ \\
\hline \multicolumn{6}{|l|}{ Peridotites } \\
\hline DTS-1 Std Value (dunite) & - & 49.59 & 929 & 2360 & 3990 \\
\hline DTS-1 powder ( 3 acids) & ---- & 8.04 & 916 & 2454 & 157 \\
\hline DTS-1 powder (hot $\mathrm{HCl}$ ) & 59.6 & $53.05 ?$ & 951 & 2530 & 20 \\
\hline UNIMIN-2 Std Value (dunite) & --- & 48.01 & $\ldots$ & 2907 & $886 ?$ \\
\hline UNIMIN-2 XRF ( $\leq 4 \%$ serp) & --- & 47.93 & 930 & 2830 & 3820 \\
\hline UNIMIN- 2 ore (hot $\mathrm{HCl})$ & 56.5 & 42.47 & 747 & 2524 & 21 \\
\hline UNIMIN-2 hand ground ore (hot $\mathrm{HCl}$ ) & 63.1 & 40.38 & 761 & 2430 & 27 \\
\hline UNIMIN-2 XRF powder (hot $\mathrm{HCl}$ ) & 53.0 & 46.89 & 830 & 2728 & 127 \\
\hline UNIMIN-1 Std Value (peridotite) & $\ldots$ & 47.65 & - & 3500 & $1710 ?$ \\
\hline UNIMIN-1 XRF (10\% serp) & ---- & 46.68 & 1005 & 140 & 3832 \\
\hline UNIMIN-1 XRF powder (hot $\mathrm{HCl}$ ) & 48.1 & 41.28 & 738 & 2479 & 657 \\
\hline PCC-1 Std Value (peridotite) & --- & 43.43 & 930 & 2380 & 2730 \\
\hline PCC-1 powder (3 acids) & --- & 8.04 & 899 & 2484 & 804 \\
\hline JP-1 Std Value (peridotite) & $\ldots$ & 44.72 & 930 & 2460 & 2970 \\
\hline JP-1 powder ( 3 acids) & - & 7.73 & 914 & 2445 & 709 \\
\hline \multicolumn{6}{|l|}{ Serpentinites } \\
\hline UB-N Std Value (100\% serp) & -.- & 35.21 & 929 & 2000 & 2300 \\
\hline UB-N powder ( 3 acids $5 / 96$ ) & -.- & $\ldots$ & 981 & 2064 & 2145 \\
\hline UB-N powder ( 3 acids $2 / 97$ ) & --- & 13.71 & 985 & 2102 & 2200 \\
\hline FG96-312 XRF (100\% serp) & --- & 33.06 & 1045 & 2514 & 2688 \\
\hline FG96-312 XRF powder (3 acids) & --- & -- & 1014 & 2312 & 1998 \\
\hline FG96-312 XRF powder $\left(60^{\circ} \mathrm{C} \mathrm{HCl}\right)$ & 48.8 & 30.92 & 765 & 2385 & 1440 \\
\hline FG96-312 XRF powder $\left(\leq 128^{\circ} \mathrm{C} \mathrm{HCl}\right)$ & 46.6 & 32.75 & 865 & 2120 & 1595 \\
\hline FG96-312 XRF powder $\left(\leq 208^{\circ} \mathrm{C} \mathrm{HCl}\right)$ & 47.5 & 32.66 & 840 & 2270 & 2135 \\
\hline FG96- $31260^{\circ} \mathrm{C}$ residue ( 3 acids) & -..- & $\ldots$ & 103 & 57 & 1481 \\
\hline FG96-312 $60^{\circ} \mathrm{C}$ (residue $+\mathrm{HCl}$ leachate) & --- & - & 868 & 2442 & 2921 \\
\hline UM96-14 XRF (85\% serp) & --- & 35.41 & 1155 & 2253 & 3054 \\
\hline UM96-14 XRF powder (hot $\mathrm{HCl}$ ) & 42.2 & 34.04 & 985 & 1960 & 1992 \\
\hline UM96-14 XRF powder (3 acids) & - & 15.19 & 1039 & 2137 & 2849 \\
\hline UM96-17 XRF (50\% serp) & - & 41.63 & 1050 & 2560 & 2794 \\
\hline UM96-17 XRF powder (hot $\mathrm{HCl}$ ) & 46.7 & 34.64 & 784 & 2141 & 185 \\
\hline UM96-17 XRF powder ( 3 acids) & - & 12.79 & 908 & 2285 & 435 \\
\hline UM96-21 XRF (40\% serp) & $\ldots$ & 44.31 & 951 & 2754 & 3160 \\
\hline UM96-21 XRF powder (hot $\mathrm{HCl}$ ) & 43.4 & 41.82 & 828 & 2398 & 25 \\
\hline UM96-21 XRF powder (3 acids) & $\ldots$ & 11.46 & 822 & 2653 & 33 \\
\hline
\end{tabular}


4. $\mathrm{HCl}$ dissolution at $60^{\circ} \mathrm{C}$ and atmospheric pressure is nearly as effective as $\mathrm{HCl}$ at $200^{\circ} \mathrm{C}$ and 15 bars for dissolving $\mathrm{Mg}$ from serpentinite (see results for sample FG96312, Table 3). However, the gain in trace metal dissolution is too small to make this procedure worthwhile.

\subsection{CALIFORNIA STUDY REGION}

At this point in our investigations, we have chosen to focus on California ultramafic bodies (Fig. 3), because their basic geology is well known, their distribution and volume is significant, their proximity to population and power manufacturing centers is favorable, their previous exploitation is well established, and one author (Goff) has previous experience with them.

California ultramafic bodies occur in four geomorphic provinces: the Coast Ranges, Big Sur, Sierra Nevada foothills belts, and the Klammoth-Trinity region (Saleeby, 1982; Harper, 1984; Dickinson et al., 1996). It is well beyond the scope of this report to review the age and tectonic history of each province in detail, but each formed during subduction-related events that occurred from about 300 to $50 \mathrm{Ma}$ (Paleozoic to Early Tertiary). Two ultramafic bodies in the Coast Ranges belt were chosen for preliminary study: The Del Puerto body because it contains a large mass of relatively unserpentinized ultramafic rock and the Wilbur Springs body because it is mostly serpentinized. Chemical analyses of all samples studied from these two bodies appear in Appendix B.

\subsection{Del Puerto Ultramafic Body}

The Del Puerto ultramafic body lies $60 \mathrm{~km}$ due east of San Jose in the California Coast Ranges (Himmelberg and Coleman, 1968). The ultramafic and surrounding rocks are well explored because they have been mined for $\mathrm{Mg}$ (magnesite), $\mathrm{Mn}$ (pyrolusite, $\mathrm{MnO}_{2}$ ), cinnabar $(\mathrm{HgS})$, and chromite (Bodenlos, 1950; Hawkes et al., 1942; Maddock, 1964). The body is part of an elongate slab of ophiolite whose ultramafic part (up to 300 $\mathrm{m}$ thick and about $40 \mathrm{~km}^{2}$ ) is variably serpentinized (Evarts and Schiffman, 1982).

The contact between ultramafic rock and underlying marine deposits of the Franciscan Complex (Jurassic to Eocene) is relatively flat and sharp. The extreme base of the ultramafic body consists of strongly foliated antigorite schist grading upward into sheared to massive, serpentinized harzburgite and local zones of dunite. The western crest of the deposit consists of material that is only $5 \%$ to $40 \%$ serpentinized and contains $\geq 45$ $\mathrm{mol} \% \mathrm{MgO}$ (Tables 1 and 2). The east end of the deposit is more highly serpentinized (Maddock, 1964; Himmelberg and Coleman, 1968).

Within the deposit, cross-cutting faults are pervasive. A set of high-angle, northwest-trending faults and fractures host magnesite veins, pods, and eroded spring deposits (Bodenlos, 1950). Considerable geochemical research has shown that the magnesite forms from groundwater alteration of the ultramafic rock and transport of $\mathrm{Mg}$ to favorable sites for precipitation (Barnes et al., 1967; 1973). Obviously, the host rocks are completely compatible with the magnesite waste that would be generated by our carbonate disposal process.

Although the magnesite has been largely mined out, the haul roads, shafts, pits, and dumps are still visible (Fig. 7a). Since World War II, the region has been mostly used for cattle ranching and hunting clubs. The ultramafic rocks are covered primarily with brush of manzanita and live oak with scattered pines. The area may be reached by paved roads from the west, east, and north. A small county park is located on the northeastern margin of the area. More recently, small subdivisions and "ranchettes" of single-family homes have been built in the San Antonio Valley on the west margin of the ophiolite. The impact of renewed mining for carbonate waste disposal would be carefully examined by the local public. Historic (and dilapidated) mining infrastructure is visible all over the Del Puerto body. 


\subsection{Wilbur Springs Serpentinite}

The Wilbur Springs serpentinite mass is located about $150 \mathrm{~km}$ NNE of San Francisco on the eastern side of the Coast Ranges (McLaughlin et al., 1989). The serpentinite is the preserved base of an extensive, north-trending sheet of ophiolite that is roughly $50 \mathrm{~km}$ long and averages 2 to $6 \mathrm{~km}$ wide. The thickness of the deposit varies from a few tens of meters on the west to several hundred meters on the east.

In contrast to the Del Puerto deposit, our examinations show that most outcrops have very little preserved peridotite minerals ( $\leq 5 \%$ overall), although original textures are occasionally well preserved. The rocks are serpentinized harzburgites that are pervasively faulted and sheared throughout much of the deposit (Fig. 7b). Typical samples from widespread locations in the mass contain about 36 $\mathrm{mol} \% \mathrm{MgO}$ (Table 2). The serpentinites overlie deformed Franciscan Complex rocks on the west and south and are overlain by Great Valley sequence marine sediments (Jurassic-Cretaceous) on the east.
A WNW-trending group of hot springs in an 8$\mathrm{km}$-long zone occurs at the extreme southern edge of the serpentinite body and is the surface expression of a small geothermal reservoir (Goff and Janik, 1993). Drilling for geothermal resources in the 1960s failed to find sufficiently high temperatures for electrical generation (reservoir temperature is $\leq 140^{\circ} \mathrm{C}$ at $>2000 \mathrm{~m}$ ). The presence of lowtemperature mineral springs, which occur sporadically throughout most of the serpentinite, indicates that modern day serpentinization is happening by reactions with groundwaters. Complexion Spring $\left(\leq 20^{\circ} \mathrm{C}\right)$, near the heart of our study area, precipitates brucite $\left(\mathrm{Mg}(\mathrm{OH})_{2}\right)$ and has a $\mathrm{pH} \leq 12$ (Barnes et al, 1972).

The southern margin of the serpentinite also hosts several small cinnabar mines, last worked in the early 1950s, and one small gold mining district that has not been worked since World War I (Peters, 1991; Goff and Janik, 1993). Homestake Mining Company reexplored the deposit in the 1980s but decided to drop their lease because of low tonnage of gold-bearing rock. Wilbur Springs proper is a small, but thriving, hot springs resort first developed before the turn of the century (Goff and Janik,

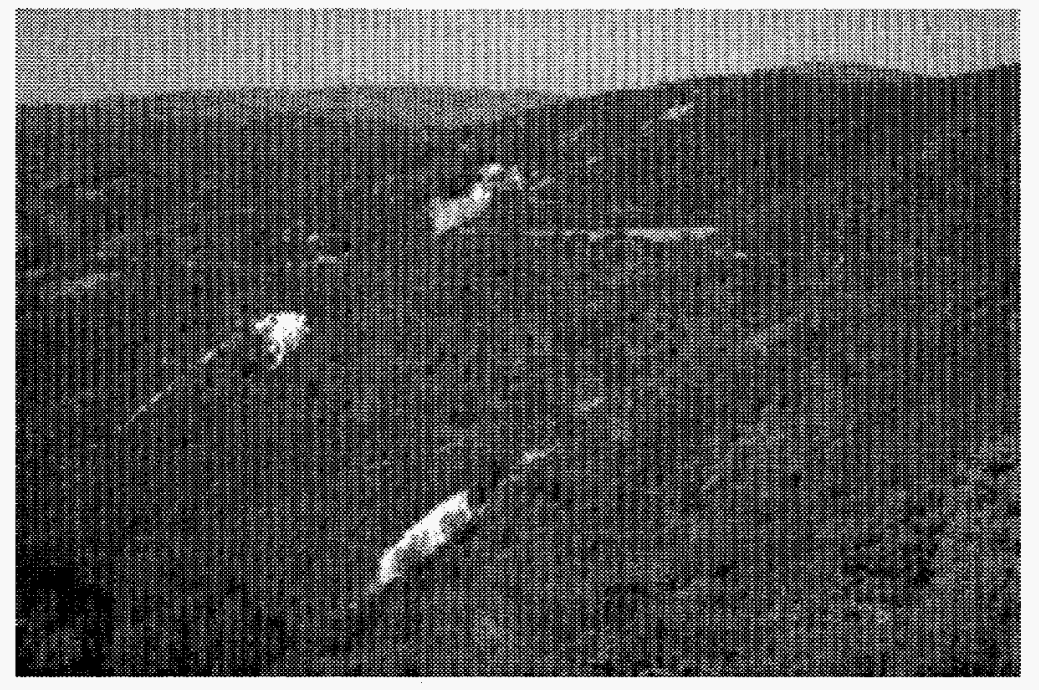

Fig. 7. (a) Looking northwest at magnesite prospects (white dumps) along the faulted western margin of the Del Puerto ultramafic body, California; note the brushy vegetation that characterizes the peridotite and dunite. (b) Outcrop along Walker Ridge Road in the Wilbur Springs serpentinite, California (rock hammer for scale); the serpentinite (sample UM96-12, Appendix B) has been sheared and fractured into blocky rubble. (a)

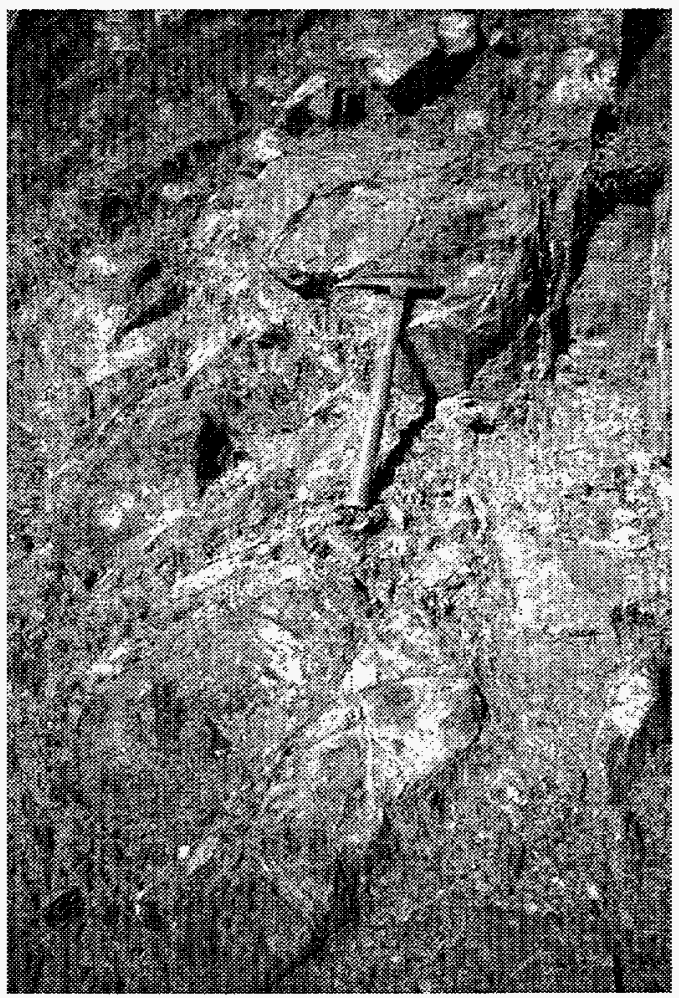

(b) 
1993). The resort now caters to people who seek quiet, natural surroundings.

Most of the land occupied by the serpentinite belongs to the US Bureau of Land Management (BLM) or to a few cattle ranches. Indian Valley on the west side of the mass contains a reservoir that is used for recreational purposes, when there is water. The serpentinite hosts scrubby vegetation consisting of manzanita, buckthorn, live oak, scattered pines, and rare cypress trees that can be nearly impenetrable to humans on foot. The area may be reached by dirt road from the south, east, and northwest.

As a precedent for open-pit mining in this region, the McLaughlin gold mine (Homestake Mining Company) was constructed in a similar geologic and physiographic environment to Wilbur Springs in the late $1970 \mathrm{~s}$. The McLaughlin mine is located about 30 to $40 \mathrm{~km}$ southwest of the Wilbur Springs serpentinite (Sherlock et al., 1995). The gold has now been mined out, and the site is being reclaimed. Processing of stockpiled ore will yield 19.2 tons of gold before Homestake abandons the site in the year 2003 (Field, 1996). A large openpit mine designed for carbonate waste disposal would probably have considerable community support in this economically depressed area. Of course, the environmental impact would have to be fully evaluated before any development were to proceed.

\subsection{DISPOSAL OF CRYSOTILE ASBES- TOS}

Serpentine minerals (chrysotile, lizardite, and antigorite) are the common hydration products of ultramafic rocks. Consequently, serpentinites host commercial deposits of chrysotile or white asbestos (Coleman, 1977; O'Hanley, 1996). Because most serpentinites contain appreciable chrysotile (usually in noncommercial form), special environmental precautions may be required during mining (Coleman, 1996). However, this is not a new issue. As noted above, mining activities are ongoing in these areas and have been for many years.
Chrysotile is a layer silicate with the ideal formula $\mathrm{Mg}_{3} \mathrm{Si}_{2} \mathrm{O}_{5}(\mathrm{OH})_{4}$ (Veblen and Wylie, 1993). It accounts for $\sim 90 \%$ of the asbestos that has been used historically in the United States (Ross, 1981), and it is the primary type of asbestos used in insulation and many other construction materials. Crysotile forms the bulk of asbestos-contaminated waste resulting from removal activities.

The health risks associated with chrysotile have been the focus of extensive scientific and public debate. Much of the debate has focused on whether chrysotile can cause mesothelioma (a rare type of cancer) in humans. Although this issue is largely unresolved, the risk from chrysotile appears to be much less than that posed by amphibole asbestos (Mossman et al., 1990). Chrysotile asbestos continues to be removed from buildings, albeit at a lower level than in years past. This asbestos-containing material must be disposed of in a landfill with special precautions prescribed by EPA (e.g., the use of a $>6$-inch cover of asbestos-free material).

Chrysotile is readily amenable to the sequestering process outlined above. For each kilogram of chrysotile, $0.48 \mathrm{~kg}$ of $\mathrm{CO}_{2}$ can be consumed in the process (i.e., $\mathrm{R}\left(\mathrm{CO}_{2}\right)=2.10$, Table 4 ). Furthermore, chrysotile dissolves rapidly relative to many other Mg-bearing silicates such as tremolite. Hume and Rimstidt (1992) studied the kinetics of chrysotile dissolution at $37^{\circ} \mathrm{C}, \mathrm{pH} 4$ to 7 and low ionic strengths as found within the human lung and found that the dissolution rate is approximately constant and zero-order with an average rate of $k=5.9 \times$ $10^{-10} \mathrm{~mol} \mathrm{~m}^{-2} \mathrm{~s}^{-1}$. They also developed a shrinking solid-cylinder model to determine the times required to dissolve completely chrysotile fibers of specific sizes. This model predicts that a chrysotile fiber would dissolve $\sim 20$ and $\sim 600$ times faster than a comparably sized fiber of amphibole or silica, respectively. In other words, chrysotile (and, probably, all of the serpentine minerals) dissolves very rapidly relative to most other phases in ultramafic rocks under conditions similar to those proposed in the sequestering process (as verified by acid dissolution experiments). 
Table 4: Mineralogy, physical-chemical properties, and $\mathrm{CO}_{2}$-sequestering properties of example peridotite/serpentinite bodies.

\begin{tabular}{|c|c|c|c|c|c|c|c|c|}
\hline & Del Puerto & Stillwater & Wilbur Spgs. & San Mateo & Vulcan Peak & Twin Sisters & Belv. Mtn. & Balt. Cplx. \\
\hline \multicolumn{9}{|l|}{ Mineralogy ${ }^{\mathrm{a}}$} \\
\hline Dunite & $\mathrm{Ol}, \mathrm{Sp}, \mathrm{Ox}, \mathrm{Cx}$ & $\mathrm{Ol}, \mathrm{Sp}$ & $-\cdots-$ & ---- & $\mathrm{Ol}, \mathrm{Sp}, \mathrm{Ox}$ & $\mathrm{Ol}, \mathrm{Ox}, \mathrm{Sp}$ & $\mathrm{Ol}, \mathrm{Sp}$ & ----- \\
\hline (alteration) & $\mathrm{Lz}, \mathrm{Cy}, \mathrm{Br}, \mathrm{Sp}$ & $\mathrm{Cy}, \mathrm{At}, \mathrm{Sp}$ & $\cdots$ & ---- & $\mathrm{Lz}, \mathrm{Cy}, \mathrm{Sp}$ & -... & $\mathrm{Ch}, \mathrm{At}, \mathrm{Br}, \mathrm{Sp}$ & ----- \\
\hline Harzburgite & $\mathrm{Ol}, \mathrm{Ox}, \mathrm{Cx}, \mathrm{Sp}$ & $\mathrm{Ol}, \mathrm{Ox}, \mathrm{Sp}, \mathrm{Pl}, \mathrm{Cx}$ & ---- & ---- & $\mathrm{Ol}, \mathrm{Ox}, \mathrm{Cx}, \mathrm{Sp}$ & $\mathrm{Ol}, \mathrm{Ox}, \mathrm{Sp}, \mathrm{Cx}$ & ..... & ----- \\
\hline (alteration) & $\mathrm{Lz}, \mathrm{Cy}, \mathrm{Br}, \mathrm{Sp}$ & $\mathrm{Ox}, \mathrm{Pl}, \mathrm{Cx}, \mathrm{Ol}, \mathrm{Sp}^{\mathrm{b}}$ & ---- & ---- & $\mathrm{Lz}, \mathrm{Cy}, \mathrm{Sp}$ & - & ---- & $-\cdots-$ \\
\hline Serpentinite & $\mathrm{Lz}, \mathrm{Cy}, \mathrm{Sp}, \mathrm{Br}$ & $\mathrm{Cy}, \mathrm{At}, \mathrm{Sp}$ & $\mathrm{Lz}, \mathrm{Cy}, \mathrm{Sp}$ & Lz, Cy, Hy, Ch & $\mathrm{Lz}, \mathrm{Cy}, \mathrm{Sp}$ & $\mathrm{At}, \mathrm{Cy}, \mathrm{Sp}$ & At, $\mathrm{Cy}, \mathrm{Sp}$ & At, Cy, Lz, Sp \\
\hline (additional) & $\mathrm{Tr}, \mathrm{At}, \mathrm{Mg}, \mathrm{Tc}, \mathrm{Ch}$ & $\mathrm{Tr}, \mathrm{TC}$ & $\mathrm{Mg}, \mathrm{Br}$ & $\mathrm{Sp}, \mathrm{Qz}$ & $\mathrm{Tr}, \mathrm{Hy}$ & $?$ & $\mathrm{Ch}, \mathrm{Br}, \mathrm{Tc}$ & $\mathrm{Tc}, \mathrm{Ch}, \mathrm{Mg}$ \\
\hline \multicolumn{9}{|l|}{ Volume-Density } \\
\hline Area $\left(\mathrm{km}^{2}\right)$ & 40 & 26 & 200 & $4 ?$ & 16 & 91 & 2.3 & 100 \\
\hline Depth $(\mathrm{km})$ & 0.3 & 0.5 & $\geq 0.2$ & 0.25 & 0.5 & 0.6 & $\leq 1$ & 0.3 \\
\hline Est. Vol. $\left(\mathrm{km}^{3}\right)$ & 12 & 13 & 40 & 1 & 8 & 54 & 2 & 30 \\
\hline Density $\left(\mathrm{g} / \mathrm{cm}^{3}\right)$ & 2.8 & 3.1 & 2.65 & 2.6 & 3.2 & 3.3 & 2.9 & 2.7 \\
\hline \multicolumn{9}{|c|}{ Wt\% Mg (Tables 1 and 2) } \\
\hline Peridotite & 27.2 & 17.5 & ---- & ---- & 27.4 & 29.9 & 29.1 & $-\ldots$ \\
\hline Serpentinite & 20.9 & ---- & 21.8 & 19.9 & ---- & --- & 23.1 & 21.2 \\
\hline Combined & 23 & 17 & 21 & 20 & 27 & 29 & 26 & 21 \\
\hline \multicolumn{9}{|c|}{ Sequestering Properties } \\
\hline $\mathrm{R}\left(\mathrm{CO}_{2}\right)^{\mathrm{c}}$ & 2.40 & 3.25 & 2.63 & 2.76 & 2.05 & 1.91 & 2.13 & 2.61 \\
\hline $\operatorname{Mg}\left(10^{9} \mathrm{t}\right)$ & 7.73 & 6.85 & 22.3 & 0.5 & 6.91 & 52.0 & 1.5 & 17.0 \\
\hline $\mathrm{CO}_{2}\left(10^{9} \mathrm{t}\right)$ & 14.0 & 12.4 & 40.3 & 0.9 & 12.5 & 94.1 & 2.7 & 30.8 \\
\hline $\mathrm{US}(\mathrm{yr})^{\mathrm{d}}$ & 2.80 & 2.48 & 8.05 & 0.18 & 2.50 & 18.8 & 0.55 & 6.15 \\
\hline World $(y r)^{d}$ & 0.74 & 0.65 & 2.12 & 0.048 & 0.66 & 4.95 & 0.14 & 1.62 \\
\hline
\end{tabular}

a At = Antigorite, $\mathrm{Br}=$ Brucite, $\mathrm{Ch}=$ Chlorite, $\mathrm{Cx}=$ Clinopyroxene, $\mathrm{Cy}=$ Clinochrysotile, $\mathrm{Hy}=\mathrm{Hydrogrossular}, \mathrm{Lz}=\mathrm{Lizardite}, \mathrm{Mg}=\mathrm{Magnesite}, \mathrm{Ol}=\mathrm{Olivine}$,

$\mathrm{Ox}=$ Orthopyroxene, $\mathrm{Pl}=$ Plagioclase, $\mathrm{Qz}=$ Quartz, $\mathrm{Sp}=$ Spinel (magnetite and chromite), $\mathrm{Tc}=\mathrm{Talc}, \mathrm{Tr}=\mathrm{Tremolite}$.

$\mathrm{b}$ Bronzitite composition from upper part of "ultramafic" series.

${ }^{c} \mathrm{R}\left(\mathrm{CO}_{2}\right)$ is the calculated mass ratio of rock processed to $\mathrm{CO}_{2}$ disposed.

${ }^{\mathrm{d}}$ Assumes annual US and world $\mathrm{CO}_{2}$ emission rates of $\sim 5 \times 10^{9}$ and $\sim 19 \times 10^{9} \mathrm{t} / \mathrm{yr}$, respectively. 


\subsection{SEQUESTERING POTENTIAL OF TYPICAL ULTRAMAFIC BODIES}

The $\mathrm{CO}_{2}$-sequestering potentials of some US ultramafic bodies are compared in Table 4. Besides listing the mineralogy of fresh and altered components, the volume, bulk density, and bulk Mg content of each body were estimated using published geologic maps, reports, and chemical analyses. Fresh peridotites, especially dunites, contain the most $\mathrm{Mg} / \mathrm{t}$ of rock. Because Stillwater peridotites contain relatively more pyroxene and less olivine, it is the least attractive peridotite body evaluated. Completely serpentinized peridotite is more reactive to hot $\mathrm{HCl}$ than fresh peridotite, but all economic tradeoffs for processing various ultramafic rocks have not been evaluated. For example, fresh peridotite is more precious and possibly more difficult to mine than typical serpentinite.

At a deposit such as the Del Puerto site $\left(\mathrm{R}\left(\mathrm{CO}_{2}\right)=\right.$ 2.40 ), every ton of sequestered $\mathrm{CO}_{2}$ would require mining, crushing, and dissolving $2.4 \mathrm{t}$ of ultramafic rock (on average). Every ton of $\mathrm{CO}_{2}$ would precipitate $1.8 \mathrm{t}$ of magnesite that would be backfilled into the open-pit mine. An additional $1.2 \mathrm{t}$ of silica and residual minerals such as pyroxenes and chromite would be backfilled with the magnesite, although some could be sold for other industrial uses. The process would also generate roughly $0.15 \mathrm{t}$ dissolved $\mathrm{Fe}$ per ton of fixed $\mathrm{CO}_{2}$ that could be precipitated as the oxide for feedstock in the steel industry.

If completely mined, the Del Puerto site would yield over $7 \mathrm{Gt}$ of $\mathrm{Mg}$, roughly $2 \mathrm{Gt}$ of $\mathrm{Fe}$, about $80 \mathrm{Mt}$ of $\mathrm{Cr}$, another $80 \mathrm{Mt}$ of $\mathrm{Ni}$, and perhaps 30 Mt of Mn. These quantities could impact the economics of existing metals industries. The dissolved $\mathrm{Mg}$ could fix $14 \mathrm{Gt}$ of $\mathrm{CO}_{2}$. Although the tonnages seem huge, the US currently generates $5 \mathrm{Gt}$ of $\mathrm{CO}_{2}$ yearly. Consequently, this deposit could sequester the equivalent of only $2.8 \mathrm{yr}$ of domestic $\mathrm{CO}_{2}$ waste and only $0.74 \mathrm{yr}$ of terrestrial $\mathrm{CO}_{2}$ waste. Larger ultramafic bodies such as the Twin Sisters dunite or the serpentinites of the Baltimore Complex could sequester considerably more $\mathrm{CO}_{2}$ over time than an intermediate-sized deposit such as the Del Puerto mass. The environmental impact of such large-scale mining and industrial processing would have to be weighed against the impact of continued $\mathrm{CO}_{2}$ emissions to the atmosphere, the risk of global climate change, and increased energy costs.

\section{ACKNOWLEDGMENTS}

We thank the following people: Klaus Lackner (T-3) for ideas and inspiration and Andy Adams (CST-7) for thin sections; Paul Canelli of UNIMIN Corp. for peridotite samples; R.G. Coleman of Stanford University for good advice; and California Division of Mines and Geology for maps and information. M. J. Aldrich (EES-1) reviewed the draft manuscript. This research was funded by a small grant from PDET (Ed Joyce), Los Alamos National Laboratory. The first author dedicates this effort to the memory of Marshall Maddock, San Jose State University.

\section{REFERENCES}

Barnes, I., LaMarche, V. C., and Himmelberg, G. R., Geochemical evidence of present-day serpentinization: Science, 156, 830, 1967.

Barnes, I., Rapp, J. B., O'Neil, J. R., Sheppard, R. A., and Gude, A. J., III, Metamorphic assemblages and the direction of flow of metamorphic fluids in four instances of serpentinization: Contrib. Mineral. Petrol., 35, 263, 1972.

Barnes, I., O'Neil, J. R., Rapp, J. B., and White, D. E., Silica-carbonate alteration of serpentine: Wall rock alteration in mercury deposits of the California Coast Ranges: Econ. Geol., 68, 388, 1973.

Berry, L. G., and Mason, B., Mineralogy: Freeman and Company, San Francisco, 630 pp., 1959.

Blok, K., Turkenburg, W. C., Hendriks, C. A., and Steinberg, M. (Eds.), Proceedings of the first international conference on carbon dioxide removal: Pergamon, Oxford, 544 pp., 1992. 
Bodenlos, A. J., Geology of the Red Mountain magnesite district, Santa Clara and Stanislaus Counties, California: Calif. J. Mines Geol., 46, 223, 1950.

Broecker, W., Will our ride into the greenhouse future be a smooth one?: GSA Today, 7, 1, 1997.

Brownlow, A. H., Geochemistry: Prentice-Hall, New York, 498 pp., 1979.

Coleman, R. G., Petrologic and geophysical nature of serpentinites: Geol. Soc. Am. Bull., 82, 897, 1971.

Coleman, R. G., Ophiolites: Springer-Verlag, New York, 229 pp., 1977.

Coleman, R. G., New Idria Serpentinite: $A$ land management dilemma: Environ. Eng. Geosci., II, 9, 1996.

Czamanske, G. K., and Zientek, M. L., The Stillwater Complex, Montana: Geology and Guide: Montana Bureau of Mines and Geology, Spec. Pub. 92, Butte, Montana, 395 pp., 1985.

Dickinson, W. R., Hopson, C. A., and Saleeby, J. B., Alternate origins of the Coast Range Ophiolite (California): Introduction and Implications: GSA Today, 6, 1, 1996.

Evarts, R. C., and Schiffman, P., Submarine hydrothermal metamorphism of the Del Puerto ophiolite, California: Amer. J. Sci., 283, 289, 1982.

Field, D., Homestake charts its course at Lower Lake's McLaughlin Mine: Lake County RecordBee, October 25, 1996.

Goff, F. and Janik, C. J., Gas geochemistry and guide for geothermal features in the Clear Lake region, California: Rytuba, J. J. (Ed.), Active geothermal systems and gold-mercury deposits in the Sonoma-Clear Lake volcanic fields, California: Soc. Econ. Geol. Guideb. Series, Vol. 16, 54 pp., 1993.
Govindaraju, K., Special issue: Geostandards Newsletter, Vol. 18, 15, 1994.

Harper, G. D., The Josephine Ophiolite, northwestern California: Geol. Soc. Am. Bull., 95, 1009 , 1984.

Hawkes, H. E., Wells, F. G., and Wheeler, D. P., Chromite and quicksilver deposits of the Del Puerto area, Stanislaus County, California: U.S. Geol. Surv. Bull. 936-D, p. 79, 1942.

Hess, H. H., Stillwater Igneous Complex, Montana: A quantitative mineralogical study: Geol. Soc. Am. Mem. 80, 225 pp., 1960.

Himmelberg, G. R., and Coleman, R. G., Chemistry of primary minerals and rocks from the Red Mountain-Del Puerto ultramafic mass, California: U.S. Geol. Surv. Prof. Paper 600-C, p. C18-C26, 1968.

Himmelberg, G. R., and Loney, R. A., Petrology of the Vulcan Peak alpine-type peridotite, southwestern Oregon: Geol. Soc. Am. Bull., 84, 1585, 1973.

Hume, L. A., and Rimstidt, J. D., The biodurability of chrysotile asbestos: Am. Mineral., 77, 1125, 1992.

Jennings, C. W., Geologic map of California: Calif. Div. Mines and Geol., Geol. Data Map 2, 1:750,000 scale (color), 1977.

Kerrick, D. M., McKibben, M. A., Seward, T. M., and Caldiera, K., Convective hydrothermal $\mathrm{CO}_{2}$ emission from high heat flow regions: Chem. Geol., 121, 285, 1995.

Lackner, K. S., Wendt, C. H., Butt, D. P., Joyce, E. L., Jr., and Sharp, D. H., Carbon dioxide disposal in carbonate minerals: Energy, 20, 1153, 1995.

Labotka, T. C., and Albee, A. L., Serpentinization of the Belvidere Mountain ultramafic body, Vermont: Mass balance and reaction at the metasomatic front: Can. Mineral., 17, 831, 1979. 
Maddock, M. E., Geologic map and sections of the Mount Boardman quadrangle, Santa Clara and Stanislaus counties, California: Calif. Div. Mines and Geol. Map Sheet 3, 1:62,500 scale (color), 1964.

McLaughlin, R. J., Ohlin, H. N., Thormahlen, D. J., Jones, D. L., Miller, J. W., and Blome, C. D., Geologic map and structure sections of the Little Indian Valley-Wilbur Springs geothermal area, northern Coast Ranges, California: U.S. Geol. Survey Misc. Invest. Map I-1706, 1:24,000 scale, (color), 1989.

Morgan, B. A., The Baltimore Complex, Maryland, Pennsylvania, and Virginia: in (R. G. Coleman and W. P. Irwin, Eds.) North American Ophiolites: Oreg. Dep. Geol. Miner. Ind. Bull., 95, 41, 1977.

Mossman, B. T., Bignon, J., Corn, M., Seaton, A., and Gee, J. B. L., Asbestos: Scientific developments and implications for public policy: Science, 247, 294, 1990.

O'Hanley, D. S., Serpentinites: Records of Tectonic and Petrological History: Oxford Monogr. Geol. and Geophys. No. 34, 277 pp., 1996.

Page, N. J., Serpentinization at Burro Mountain, California: Contrib. Mineral. Petrol., 14, 321, 1967.

Peters, E. K., Gold-bearing hot spring systems of the northern coast ranges, California: Econ. Geol., 86, 1519, 1991.

Pouchou, J. L. and Pichoir F., PAP Procedure for improved quantitative microanalysis, Microbeam Analysis, J. T. Armstrong, Ed., San Francisco Press, Inc., 3 pp., 1985.

Ragan, D. M., Emplacement of the Twin Sisters Dunite, Washington: Am. J. Sci., 261, 549, 1963.
Ramanathan, $\mathrm{V}$., The greenhouse theory of climate change: A test by an inadvertent global experiment: Science, 240, 293, 1988.

Rice, S. J., Asbestos, in Wright, L. A., Ed., Mineral Commodities of California: Calif. Div. Mines Bull., 176, 49, 1957.

Ross, M., The geologic occurrences and health hazards of amphibole and serpentine asbestos, in (D. R. Veblen, Ed.) Amphiboles and Other Hydrous Pyriboles-Mineralogy, 9A: Mineralogical Society of America, Washington, DC, p. 279, 1981.

Saleeby, J. B., Polygenetic ophiolite belt of the California Sierra Nevada: geochronological and tectonostratigraphic development: J. Geophys. Res., 87, 1803, 1982.

Sherlock, R. L., Tosdal, R. M., Lehrman, N. J., Graney, J. R., Losh, S., Jowett, E. C., and Kesler, S. E., Origin of the McLaughlin Mine sheeted vein complex: metal zoning, fluid inclusion, and isotopic evidence: Econ. Geol., 90, 2156, 1995.

Thayer, T.P., The Canyon Mountain Complex, Oregon, and some problems of ophiolites: in (R. G. Coleman and W. P. Irwin, Eds.) North American Ophiolites: Oreg. Dep. Geol. Min. Ind. Bull., 95, 93, 1977.

United Nations, 1993 Energy Statistics Yearbook: New York, 492 pp., 1995.

Veblen, D. R., and Wylie, A. G., Mineralogy of amphiboles and 1:1 layer silicates, in (G. D. Guthrie, Jr., and B. T. Mossman, Eds.), Health Effects of Mineral Dusts, Vol. 28, Mineralogical Society of America, Washington, p. 61. 1993.

Weart, S. R., The discovery of the risk of global warming: Phys. Today (January), pp. 34-40, 1997. 
A scheme was developed for rapid identification of primary and secondary minerals in ultramafic rocks using the electron microprobe (EMP). As an example, we first examined by petrographic microscope the minerals present in a polished thin section made from a densely packed grain mount of crushed rock from the Green Mountain Peridotite, North Carolina. This examination revealed that the perdiotite grains were composed of about $70 \%$ olivine, pyroxene, and chromite (primary minerals). Other possible phases (secondary minerals) included talc, phlogopite, chlorite, serpentine, anthophyllite, tremolite, brucite, and magnesite. Next, a generic EMP analysis file was created to quantify the elements $\mathrm{Si}, \mathrm{Al}, \mathrm{Fe}, \mathrm{Mn}, \mathrm{Ni}, \mathrm{Ti}, \mathrm{Cr}, \mathrm{Ca}, \mathrm{Na}, \mathrm{Mg}$, and $\mathrm{K}$ to provide information on as many mineral phases as possible. No attempt was made to account for water in known hydrous minerals such as talc and serpentine, and for possible presence of fluorine and chlorine. PAP matrix corrections were used to reduce the raw data (Pouchou and Pichoir, 1985). Because Mg-rich silicate phases were the specific target of this thin section reconnaissance, analyses of $\mathrm{Fe}-\mathrm{Cr}$ oxide minerals were not studied further. We did not identify brucite or magnesite in our grain mount of this rock. Analyses with totals less than $80 \mathrm{wt} \%$ were rejected. Cations were normalized to six oxygen atoms per unit cell for all analyses to promote mineral recognition by chemical stoichiometry.

Initial microprobe analysis of about 50 randomly selected grains verified that olivine (approximately Fo90) was the dominant phase. In order to sample as many other phases as possible, olivine grains were avoided during the second step of data acquisition (100 randomly selected grains) in which talc, tremolite, chlorite, serpentine, pyroxene, chrome spinel, and the ubiquitous olivine were identified. Phase identification was based on general chemistry and cation ratios. Specifically, a plot of Si cations versus Sum ( $\mathrm{Fe}+\mathrm{Mg}$ ) cations (Fig. A-1) clearly separates the phases present and is especially useful in identifying minerals that may have appreciable cation substitution such as serpentine. This analytical scheme provides rapid identification and compositional information on the silicate alteration phases $(>1$ modal\%) that typically occur within ultramafic rocks.

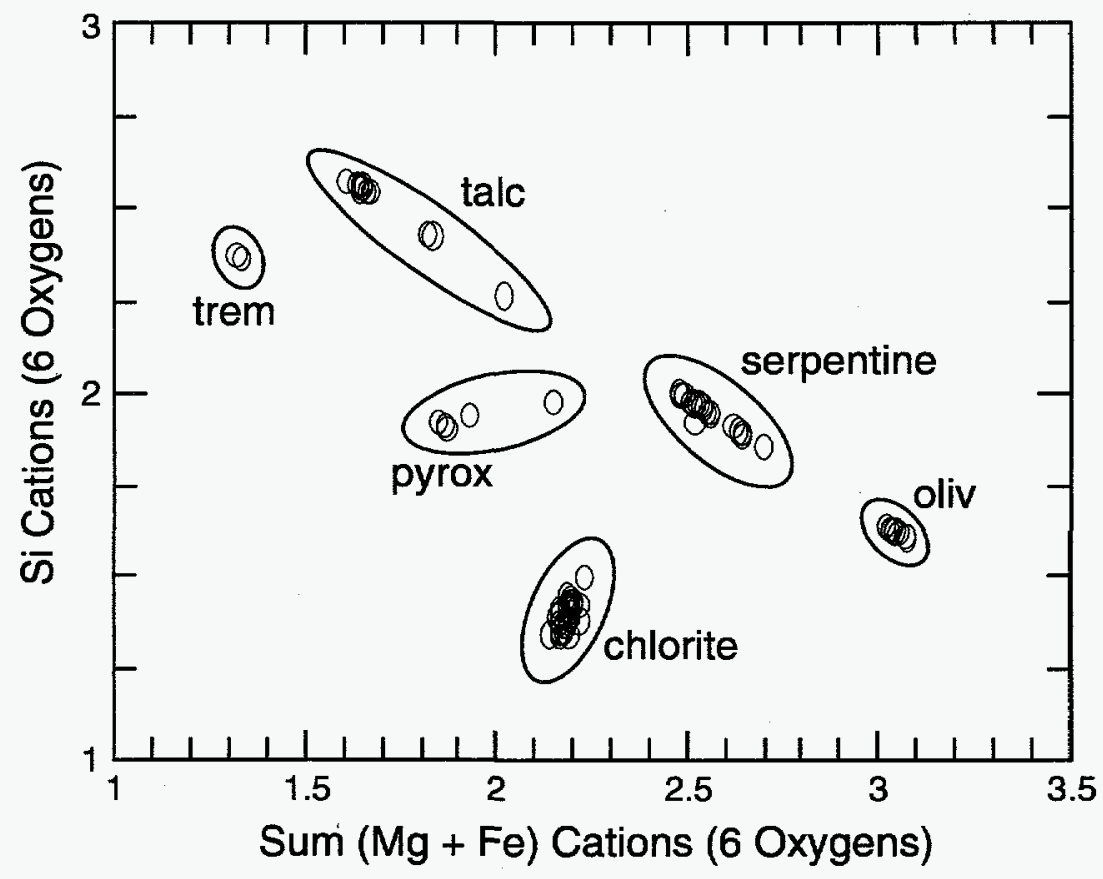

Fig. A-1: Plot of Si cations versus sum $(\mathrm{Fe}+\mathrm{Mg}$ ) cations for the 100 grains analyzed in step two of the microprobe investigation. Secondary minerals in slightly metamorphosed Green Mountain Peridotite form distinct populations of points. Trem $=$ tremolite; pyrox $=$ pyroxene oliv $=$ olivine . 
Appendix B. Table of chemical analyses of ultramafic rocks investigated during this project (X-ray fluorescence and FeO analyses by EES-1).

\begin{tabular}{|c|c|c|c|c|c|c|c|c|c|c|c|}
\hline Sample & UM96-1 & UM96-2 & UM96-3 & UM96-4 & UM96-5 & UM96-6 & UM96-7 & UM96-8 & UM96-9 & UM96-10 & UM96-11 \\
\hline Location $^{\mathrm{a}}$ & W Spgs & W Spgs & W Spgs & W Spgs & W Spgs & W Spgs & W Spgs & W Spgs & W Spgs & W Spgs & W Spgs \\
\hline Name $^{b}$ & Hzbgite & Hzbgite & Hzbgite & Hzbgite & Hzbgite & Hzbgite & Hzbgite & Hzbgite & Hzbgite & Hzbgite & Hzbgite \\
\hline T. S. $^{\mathrm{c}}$ & $\mathbf{N}$ & $\mathrm{Y}$ & $\mathrm{N}$ & $\mathrm{Y}$ & $\mathbf{N}$ & $\mathbf{N}$ & $\mathbf{Y}$ & $\mathbf{N}$ & $\mathbf{N}$ & $\mathbf{N}$ & $\mathrm{N}$ \\
\hline Style & sheared & sheared & sheared & massive & sheared & massive & massive & massive & massive & sheared & sheared \\
\hline $\operatorname{Serp}(\%)^{\mathrm{d}}$ & --.- & 100 & ---- & 95 &.-- & ---- & 75 & ---- & --- & ---- & --- \\
\hline \multicolumn{12}{|c|}{ Major oxides (wt $\%)$} \\
\hline $\mathrm{SiO}_{2}$ & 40.79 & 41.25 & 39.75 & 39.85 & 39.91 & 40.26 & 41.85 & 41.70 & 41.54 & 40.66 & 39.87 \\
\hline $\mathrm{TiO}_{2}$ & 0.031 & 0.066 & 0.080 & 0.040 & 0.023 & 0.057 & 0.000 & 0.048 & 0.037 & 0.048 & 0.030 \\
\hline $\mathrm{Al}_{2} \mathrm{O}_{3}$ & 1.57 & 2.10 & 2.28 & 1.51 & 1.46 & 2.05 & 0.50 & 2.19 & 1.59 & 2.56 & 2.05 \\
\hline $\mathrm{Fe}_{2} \mathrm{O}_{3}$ & 6.10 & 7.62 & 6.80 & 6.96 & 5.49 & 6.64 & 6.58 & 4.91 & 5.67 & 5.65 & 5.89 \\
\hline $\mathrm{FeO}$ & 1.90 & 1.26 & 1.38 & 1.40 & 2.21 & 1.43 & 1.02 & 3.00 & 1.70 & 2.39 & 2.30 \\
\hline $\mathrm{MnO}$ & 0.143 & 0.134 & 0.147 & 0.149 & 0.135 & 0.135 & 0.126 & 0.129 & 0.137 & 0.120 & 0.149 \\
\hline $\mathrm{MgO}$ & 36.32 & 34.14 & 34.61 & 37.08 & 37.01 & 35.56 & 37.13 & 36.64 & 36.33 & 35.79 & 36.38 \\
\hline $\mathrm{CaO}$ & 0.00 & 0.39 & 0.17 & 0.00 & 0.54 & 0.41 & 0.27 & 1.63 & 0.50 & 0.00 & 0.32 \\
\hline $\mathrm{Na}_{2} \mathrm{O}$ & 0.00 & 0.00 & 0.00 & 0.00 & 0.00 & 0.00 & 0.00 & 0.00 & 0.00 & 0.00 & 0.00 \\
\hline $\mathrm{K}_{2} \mathrm{O}$ & 0.00 & 0.00 & 0.00 & 0.00 & 0.00 & 0.00 & 0.00 & 0.00 & 0.00 & 0.00 & 0.00 \\
\hline $\mathrm{P}_{2} \mathrm{O}_{5}$ & $\quad 0.00$ & 0.00 & 0.00 & 0.00 & 0.00 & 0.00 & 0.00 & 0.00 & 0.00 & 0.00 & 0.00 \\
\hline LOI & 13.28 & 13.56 & 13.76 & 13.44 & 12.80 & 13.49 & 12.82 & 9.46 & 12.53 & 12.81 & 12.92 \\
\hline \multicolumn{12}{|c|}{ Selected trace elements (ppm) } \\
\hline $\mathrm{V}$ & 51.0 & 53.2 & 79.4 & 40.8 & 33.3 & 61.1 & 15.9 & 59.2 & 36.2 & 67.1 & 57.2 \\
\hline $\mathrm{Cr}$ & 2830 & 3070 & 3050 & 2850 & 2850 & 2660 & 3200 & 2830 & 2770 & 2830 & 2790 \\
\hline $\mathrm{Ni}$ & 2460 & 2630 & 2670 & 2890 & 2550 & 2410 & 2610 & 2360 & 2770 & 2480 & 2510 \\
\hline $\mathrm{Zn}$ & 75.0 & 48.5 & 71.1 & 74.2 & 57.8 & 63.8 & 46.3 & 51.3 & 75.6 & 66.8 & 60.8 \\
\hline Total (wt\%) & 100.7 & 101.1 & 99.55 & 101.0 & 100.1 & 100.5 & 100.9 & 100.2 & 100.6 & 100.6 & 100.4 \\
\hline
\end{tabular}


Appendix B (continued)

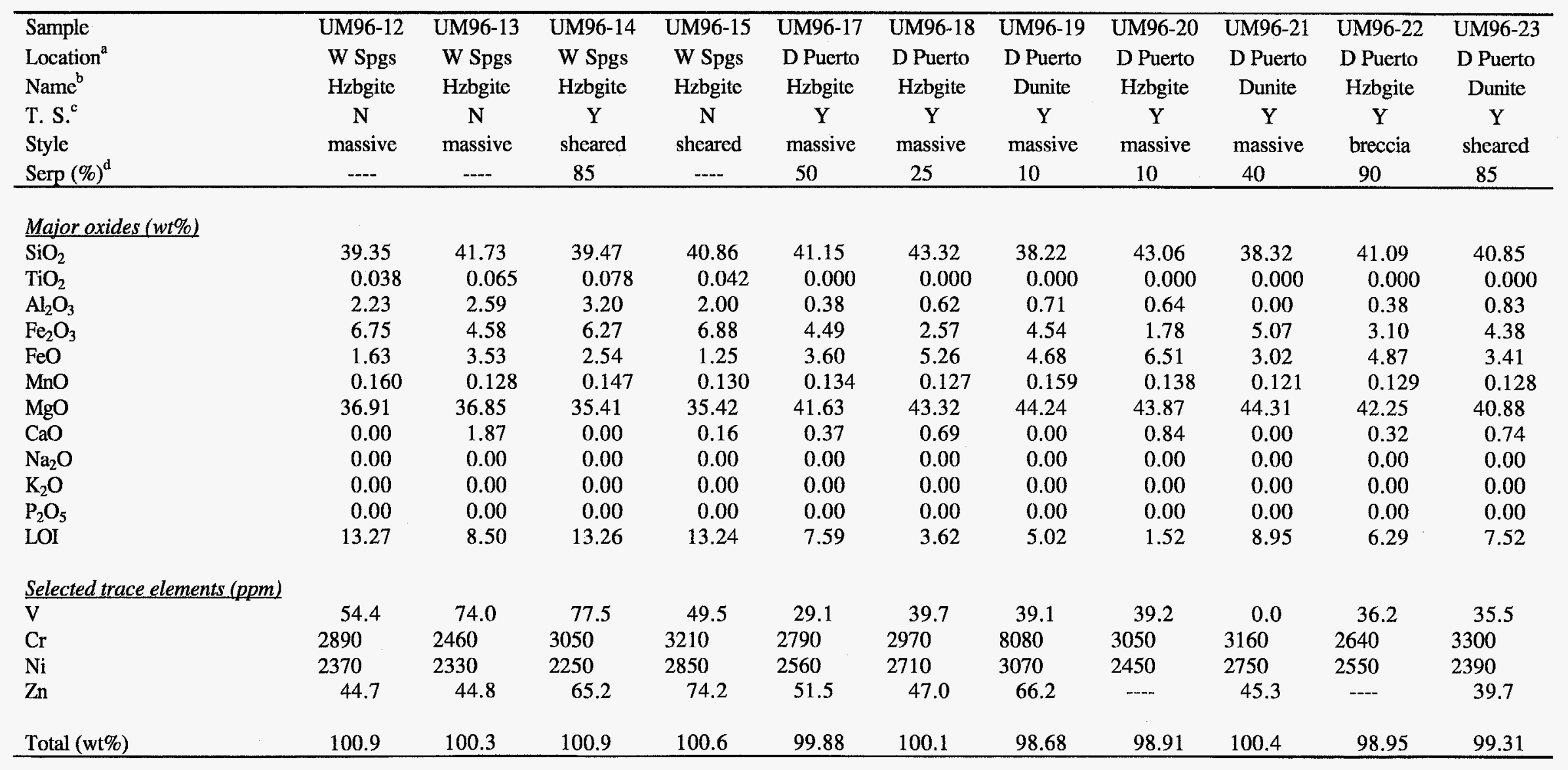


Appendix B (continued)

\begin{tabular}{|c|c|c|c|c|c|c|c|}
\hline Sample & UM96-24 & UM96-25 & UM96-26 & UMIN-1 & UMIN-1 ${ }^{\mathrm{e}}$ & UMIN-2 & UMIN-2 $2^{\mathrm{f}}$ \\
\hline Location $^{\mathrm{a}}$ & D Puerto & D Puerto & D Puerto & G Mtn & G Mtn & T Sisters & T Sisters \\
\hline Name $^{b}$ & Dunite & Dunite & Lherz & Perid & Perid & Dunite & Dunite \\
\hline T. $S^{c}$ & $\mathrm{Y}$ & $\mathrm{Y}$ & $\mathrm{Y}$ & $\mathrm{Y}$ & ---- & $\mathrm{Y}$ & ---- \\
\hline Style & massive & massive & massive & sand & $-\cdots$ & sand & ---- \\
\hline $\operatorname{Serp}(\%)^{\mathrm{d}}$ & 60 & 45 & 75 & 10 & $-\cdots$ & $<5$ & ---- \\
\hline \multicolumn{8}{|c|}{ Major oxides (wt\%) } \\
\hline $\mathrm{SiO}_{2}$ & 39.34 & 39.12 & 40.87 & 42.07 & 41.00 & 41.23 & 42.52 \\
\hline $\mathrm{TiO}_{2}$ & 0.000 & 0.000 & 0.000 & 0.000 & ---- & 0.000 & ---- \\
\hline $\mathrm{Al}_{2} \mathrm{O}_{3}$ & 0.00 & 0.00 & 0.32 & 0.63 & 0.80 & 0.00 & 0.19 \\
\hline $\mathrm{Fe}_{2} \mathrm{O}_{3}$ & 5.31 & 5.67 & 5.49 & 1.44 & $8.00^{\mathrm{T}}$ & 1.23 & $7.68^{\mathrm{T}}$ \\
\hline $\mathrm{FeO}$ & 3.66 & 3.27 & 1.88 & 5.81 & $\ldots$ & 6.54 & ---- \\
\hline $\mathrm{MnO}$ & 0.131 & 0.140 & 0.141 & 0.125 & --- & 0.120 & ---- \\
\hline $\mathrm{MgO}$ & 42.76 & 43.02 & 34.78 & 46.68 & 47.65 & 47.93 & 48.01 \\
\hline $\mathrm{CaO}$ & 0.00 & 0.00 & 5.76 & 0.23 & 0.35 & 0.15 & 0.02 \\
\hline $\mathrm{Na}_{2} \mathrm{O}$ & 0.00 & 0.00 & 0.00 & 0.00 & ---- & 0.00 & 0.02 \\
\hline $\mathrm{K}_{2} \mathrm{O}$ & 0.00 & 0.00 & 0.00 & 0.00 & ---- & 0.00 & 0.01 \\
\hline $\mathrm{P}_{2} \mathrm{O}_{5}$ & 0.00 & 0.00 & 0.00 & 0.00 & --- & 0.00 & ---- \\
\hline LOI & 7.25 & 8.30 & 11.33 & 2.11 & 1.60 & 0.43 & 1.05 \\
\hline \multicolumn{8}{|c|}{ Selected trace elements ( $\mathrm{ppm}$ ) } \\
\hline $\mathrm{V}$ & 12.3 & 19.7 & 29.0 & 31.6 & --- & 0.0 & ---- \\
\hline $\mathrm{Cr}$ & 3470 & 3050 & 2820 & 3730 & $1710 ?$ & 3820 & $890 ?$ \\
\hline $\mathrm{Ni}$ & 2580 & 2670 & 911 & 2670 & 3500 & 2830 & 2900 \\
\hline $\mathrm{Zn}$ & 55.0 & 46.2 & 31.7 & ---- & ---- & ---- & ---- \\
\hline Total (wt\%) & 99.06 & 100.1 & 100.9 & 99.74 & 99.92 & 98.30 & 99.88 \\
\hline
\end{tabular}

${ }^{a}$ Locations listed are Wilbur Springs (CA), Del Puerto (CA), Green Mountain (NC), and Twin Sisters (WA).

${ }^{\mathrm{b}}$ Hzbgite $=$ harzburgite, Lherz $=$ lherzolite, Perid $=$ peridotite.

${ }^{\mathrm{c}} \mathrm{T} . \mathrm{S} .=$ polished thin section used for mineral and textural examination.

¿ Percent serpentine alteration estimated from thin section examination.

${ }^{e}$ Analysis provided by Unimin Corporation.

${ }^{i}$ Total $\mathrm{Fe}$ as $\mathrm{Fe}_{2} \mathrm{O}_{3}$ 